\title{
INSTRUMENTOS ECONÔMICOS \\ DE GARANTIA DE REPARAÇÃO DE DANOS AMBIENTAIS: ELEMENTOS CONCEITUAIS SOBRE OS SEGUROS AMBIENTAIS
}

\author{
INSTRUMENTOS ECONÓMICOS \\ PARA LA GARANTÍA DE REPARACIÓN DE DAÑOS \\ AMBIENTALES: ELEMENTOS CONCEPTUALES \\ SOBRE SEGUROS AMBIENTALES
}

\author{
ECONOMIC INSTRUMENTS \\ FOR ENVIRONMENTAL DAMAGE REPAIR \\ GUARANTEE: CONCEPTUAL ELEMENTS ON \\ ENVIRONMENTAL INSURANCE
}

PERY SARAIVA NETO*

Fecha de recepción: 10 de octubre 2019

Fecha de aceptación 30 noviembre 2019 Disponible en línea: 30 de diciembre 2019

Para citar este artículo/To cite this article

Saraiva Neto, Pery, Instrumentos econômicos de garantia de reparação de danos ambientais: Elementos conceituais sobre os seguros ambientais, 51 Rev.Ibero-Latinoam.Seguros, 157-200

(2019). https://doi.org/10.11144/Javeriana.ris51.iegr

doi:10.11144/Javeriana.ris51.iegr

\footnotetext{
* Doutor em Direito/PUCRS, com estágio doutoral na Universidade de Coimbra-FDUC (PDSE/CAPES). Mestre em Direito/UFSC. Especialista em Direito Ambiental pela FUNJAB/ UFSC. Professor de pós-graduação. Presidente do Grupo Nacional de Trabalho em Seguro Ambiental da AIDA/Brasil. Membro da Associação dos Professores de Direito Ambiental do Brasil (APRODAB). Membro Fundador da União Brasileira da Advocacia Ambiental (UBAA). Autor e colaborador de diversos estudos jurídicos sobre meio ambiente e seguros. Advogado e consultor jurídico.
} 


\section{RESUMO}

O estudo desenvolvido no presente artigo tem por objetivo investigar os denominados seguros ambientais. Busca-se enfrentar questões relacionadas aos pressupostos, amplitudes, regulamentação e eficácia deste instrumento econômico de garantia de reparação de danos ambientais. Para tanto parte-se da investigação da ideia e do conceito de riscos ambientais como baliza para a compreensão da infortunística ambiental e do sistema de responsabilidade civil ambiental no Brasil. Fixados esses elementos conceituais iniciais analisase como a legislação trata da incorporação de mecanismos de seguros para fazer frente à reparação dos danos ambientais, sendo apontadas, nessa legislação, falhas que implicam inclusive sua não efetividade. Para fixar bases de superação dessa falta de efetividade, o instituto dos seguros é estudado em seus elementos, origens, funcionalidades e características, no intuito de compreender as formas de assegurar os riscos ambientais. Demonstra-se uma assimetria entre o sistema de responsabilidades ambientais e o de atuação dos seguros, segundo a ótica de definição e delimitação do risco ambiental e do risco assegurável. Propõe-se a necessidade de um modelo legislativo sistematicamente coerente e previsível, na forma de uma política de garantias para fazer frente ao dever de reparação dos danos ao meio ambiente, envolvendo a delimitação do risco, da infortunística e das formas de reparação dos danos ambientais, e que contenha clareza e demarcação a respeito dos riscos ambientais que devem ser suportados pelos seguros, em conformidade com os objetivos legais que moveram a instituição desses instrumentos econômicos.

Palavras-Chave: Riscos, Danos Ambientais, Reparação, Garantia, Seguros.

\section{RESUMEN}

El estudio desarrollado en la presente ponencia tiene por objetivo investigar los denominados seguros ambientales. Se busca enfrentar cuestiones relacionadas a los supuestos, alcances, regulación y eficacia de este instrumento económico de garantía de reparación de daños ambientales. Para este propósito, se parte de la investigación de la idea y del concepto de riesgos ambientales, como referencia para la comprensión de la infortuna ambiental y del sistema de responsabilidad civil ambiental en Brasil. Fijados esos elementos conceptuales iniciales, se analiza como la legislación trata la incorporación de mecanismos de seguros para hacer frente a la reparación de los daños ambientales, siendo señaladas en esa legislación, fallas que presuponen incluso su no efectividad. Para fijar las bases de superación de esa falta de efectividad, la institución de seguros es estudiada en sus elementos, orígenes, funcionalidades y características, a fin de comprender las formas de asegurar los riesgos ambientales. Asimismo, se demuestra una asimetría entre el sistema de responsabilidades ambientales y el de la actuación de los seguros, según la óptica de definición y delimitación del riesgo ambiental y del riesgo asegurable. Se propone la necesidad de un modelo legislativo sistemáticamente coherente y previsible, a modo de una política de garantías para hacer frente al deber de reparación de los daños al medio ambiente, incluyendo la delimitación del riesgo, la de la infortuna y de las formas de reparación de los daños ambientales, que contenga, claridad y demarcación al respecto de dichos riesgos, que deben ser asumidos por los Seguros, de conformidad con los objetivos legales que moverán la Institución de esos instrumentos económicos.

Palabras Clave: Riesgos, Daños Ambientales, Reparación, Garantía, Seguros. 


\begin{abstract}
The study developed in this article aims to investigate environmental insurance. The research will address issues related to the assumption, magnitude, regulation and effectiveness of this economic tool used to guarantee repair of environmental damages. It is the goal of the investigation to demonstrate the idea and the concept of environmental risks as a beacon for the understanding of environmental negligence and the environmental civil liability system in Brazil. Once these initial conceptual elements have been fixed, the study analyzes how the legislation deals with the incorporation of risk mechanisms to deal with the repair of environmental damage, and in this legislation, flaws that imply its non-effectiveness are also pointed out. In order to establish a basis for overcoming this lack of effectiveness, the insurance institute is studied in its elements, origins, functionalities and characteristics, in order to understand the ways of ensuring environmental risks. There is an imbalance between the system of environmental responsibilities and that of insurance operations, according to the definition and control of environmental risk and insurance risk. There is a need for a systematically logical and anticipated legislative model, in the form of a policy that guarantees to meet the obligation to repair environmental damage, involving the control of risk, misfortune and ways of alleviating environmental damage; which contains clarity and differentiation regarding the environmental risks that must be produced by insurance, in accordance with the legal objectives that moved the establishment of these economic tools.
\end{abstract}

Keywords: Risks, Environmental Damage, Repair, Insurance.

\title{
SUMARIO
}

1 INTRODUÇÃO - ESBOÇO GERAL DOS MARCOS LEGAIS SOBRE SEGUROS AMBIENTAIS NO BRASIL: DAIMPRECISÃO À LOCALIZAÇÃO DE CONCEITOS. 2. ATIVIDADE E TÉCNICA SEGURADORA PELA DISPERSÇÃODOSRISCOS:ESSENCIALIDADEEORIGENS.3.ATIVIDADE E TÉCNICA SEGURADORA PELA DELIMITAÇÃO DOS RISCOS. 4. CLASSIFICAÇÃO DOS SEGUROS. 5. DEFINIÇÃO DO BENEFICIÁRIO DO SEGURO E REDIMENSIONAMENTO DO TERCEIRO LESADO NA RESPONSABILIDADE CIVIL AMBIENTAL. 6. RESPONSABILIDADE INTEGRAL: FORMAS DE REPARAÇÃO DE DANOS E A ATUAÇÃO DOS SEGUROS POR MEIO DAS COBERTUAS E INDENIZAÇÕES. 6.1. DANOS ECOLÓGICOS, VALORAÇÃO, MARCO DE REPARAÇÃO E DESPESAS DE CONTENÇÃO: TOMADA DE POSIÇÃO. 6.2. OS SEGUROS DIANTE OS DANOS AMBIENTAIS DIFUSOS E EXTRAPATRIMONIAIS. 6.3. OS DANOS INDIVIDUAIS E SUA PROJEÇÃO MASSIFICADA: TOMADA DE POSIÇÃO PELOS SEGUROS OBRIGATÓRIOS EM UM MODELO DE FIRST-PARTY INSURANCE. 7. O SEGURO GARANTIA AMBIENTAL. 8. CONSIDERAÇÕES FINAIS. 9. REFERÊNCIAS. 


\section{INTRODUÇÃO - ESBOÇO GERAL DOS MARCOS LE- GAIS SOBRE SEGUROS AMBIENTAIS NO BRASIL: DA IMPRECISÃO À LOCALIZAÇÃO DE CONCEITOS}

O movimento de desenvolvimento do seguro ambiental no Brasil não é novo: na década de 1970 tiveram origem as primeiras iniciativas de sua implementação, com a chegada de clausulados de seguros ambientais trazidos por segurador norte-americano aqui estabelecido. Desde então, houve esforços para o desenvolvimento do mercado e para o estabelecimento de marcos normativos. 1

No Brasil, a previsão legal sobre seguro ambiental aparece pioneiramente no ano de 2006, em alterações à Lei 6.938/1981 - a Lei da Política Nacional do Meio Ambiente (LPNMA). A LPNMA, com posteriores modificações, fixou como um de seus princípios (artigo $2^{\circ}$, VIII) o da "reparação de áreas degradadas" e estabeleceu entre seus objetivos a "restauração dos recursos ambientais com vistas à sua utilização racional e disponibilidade permanente, concorrendo para a manutenção do equilíbrio ecológico propício à vida" (artigo $4^{\circ}$, inciso VI), bem como a "imposição, ao poluidor e ao predador, da obrigação de recuperar e/ou indenizar os danos causados e, ao usuário, da contribuição pela utilização de recursos ambientais com fins econômicos" (artigo $4^{\circ}$, inciso VII).

Os dispositivos legais acima referidos consagraram o princípio do poluidor-pagador na política ambiental brasileira. No artigo $9^{\circ}$, são elencados os instrumentos da PNMA e, em 2006, a Lei 11.284/2006 introduziu o inciso XIII no referido artigo, para instituir os instrumentos econômicos, dentre os quais a concessão florestal, a servidão ambiental e, como novidade, o "seguro ambiental". Não há, no entanto, qualquer definição sobre o seguro proposto pelo legislador, em termos de sua natureza ou das espécies de riscos que estariam sob o foco de proteção especial.

A inserção do seguro ambiental entre os instrumentos econômicos da LPNMA adveio no intuito de dar coerência aos objetivos da Lei 11.284/2006, que trata da gestão de florestas públicas para a produção sustentável e institui na estrutura do Ministério do Meio Ambiente o Serviço Florestal Brasileiro. Entre os objetivos dessa lei, está a con-

1 Sobre o desenvolvimento dos seguros ambientais no Brasil, ver POLIDO, Walter. Seguros para riscos ambientais. São Paulo: Revista dos Tribunais, 2005, p. 207 e seguintes. Como sugestão de compreensão histórica do recente desenvolvimento dos seguros, de forma ampla, consultar CARLINI, Angélica. A atividade de seguro no Brasil nos últimos cinquenta anos. Assicurazioni - Rivista di diritto, economia e finanza delle assicurazioni private. Roma: Fondazione Assicurazioni Generali, anno LXXV, n. 4, ottobre-dicembre, 2008, p. 519-548. 
cessão de florestas $2 \underline{2}$ do Poder Público aos particulares, para a exploração de produtos e serviços florestais.

No artigo 20, ao tratar do edital de licitação das concessões, determina-se a necessidade de descrição das garantias financeiras e dos seguros exigidos (inciso XIII). Ao especificar as garantias, assim estabelece:

Art. 21. As garantias previstas no inciso XIII do art. 20 desta Lei:

I - incluirão a cobertura de eventuais danos causados ao meio ambiente, ao erário e a terceiros;

II - poderão incluir, nos termos de regulamento, a cobertura do desempenho do concessionário em termos de produção florestal.

$\S 1^{\circ} \mathrm{O}$ poder concedente exigirá garantias suficientes e compatíveis com os ônus e riscos envolvidos nos contratos de concessão florestal.

$\S 2^{\circ}$ São modalidades de garantia:

I - caução em dinheiro;

II-títulos da dívida pública emitidos sob a forma escritural, mediante registro em sistema centralizado de liquidação e de custódia autorizado pelo Banco Central do Brasil, e avaliados pelos seus valores econômicos, conforme definido pelo Ministério da Fazenda; III-seguro-garantia;

IV-fiança bancária;

V-outras admitidas em lei.

$\mathrm{Na}$ mesma lei, é tratada a figura do seguro. O artigo 44 e seguintes abordam a possibilidade de extinção da concessão - especificamente o artigo 45, o qual dispõe:

A inexecução total ou parcial do contrato acarretará, a critério do poder concedente, a rescisão da concessão, a aplicação das sanções contratuais e a execução das garantias, sem prejuízo da responsabilidade civil por danos ambientais prevista na Lei $\mathrm{n}$.

\footnotetext{
2 Sobre a concessão de florestas, segundo Morato Leite: “[...] consiste em delegação onerosa realizada pelo Poder concedente do direito de praticar manejo florestal sustentável para exploração de produtos e serviços florestais, em unidade de manejo, mediante licitação, à pessoa jurídica, em consórcio ou não, que atenda às exigências do edital e demonstre capacidade para seu desempenho, por sua conta e risco. É importante lembrar que as comunidades locais poderão participar das licitações relativas a concessões florestais, por meio de associações comunitárias, cooperativas ou outras pessoas jurídicas admitidas em lei. LEITE, José Rubens Morato. Manual de direito ambiental (coord.). São Paulo: Saraiva, 2015, p. 370.
} 
6.938, de 31 de agosto de 1981, e das devidas sanções nas esferas administrativa e penal.

De acordo com o $\S 6^{\circ}$, o Poder Público poderá instituir seguro para cobertura da indenização prevista no inciso IX do $\S 1^{\circ}$ do artigo 45 , nos casos em que "ocorrer fato superveniente de relevante interesse público que justifique a rescisão, mediante lei autorizativa específica, com indenização das parcelas de investimento ainda não amortizadas vinculadas aos bens reversíveis que tenham sido realizados". A referida norma, portanto, trata de seguros e propõe a possibilidade de coberturas para: (i) danos causados (ao ambiente, ao erário e a terceiros), (ii) desempenho; e (iii) para indenização do concessionário em caso de rescisão pelo Poder Público.

Diante de tão amplas possibilidades de seguros, deve-se questionar qual seja, ou o que seja, o seguro ambiental. Será o seguro ambiental um gênero, válido para todos os tipos de riscos que envolvam atividades com implicações ambientais, independentemente dos beneficiários, riscos ou interesses? Ou o seguro ambiental é um tipo contratual específico? Responder a tais perguntas requer avançar sobre outras normativas legais vigentes.

Ainda outras legislações introduzem o recurso aos seguros ambientais, valendo-se, para tanto, de diversas nomenclaturas, semelhantes àquelas acima referidas. Todas elas, no entanto, carecem de clareza sobre a modalidade e amplitude do seguro proposto.

Em 2010, foi instituída a Lei 12.305/2010, que trata da Política Nacional de Resíduos Sólidos. Esta lei foi regulamentada pelo Decreto 7.404/2010 e trata do referido seguro em seu artigo $67 .{ }^{3}$ Prevê, em seu artigo 40:

No licenciamento ambiental de empreendimentos ou atividades que operem com resíduos perigosos, o órgão licenciador do Sisnama pode exigir a contratação de seguro de responsabilidade civil por danos causados ao meio ambiente ou à saúde pública, observadas as regras sobre cobertura e os limites máximos de contratação fixados em regulamento.

Parágrafo único. O disposto no caput considerará o porte da empresa, conforme regulamento. com resíduos perigosos, o órgão licenciador do SISNAMA pode exigir a contratação de seguro de responsabilidade civil por danos causados ao meio ambiente ou à saúde pública, observadas as regras sobre cobertura e os limites máximos de contratação estabelecidos pelo Conselho Nacional de Seguros Privados - CNSP. Parágrafo único. A aplicação do disposto no caput deverá considerar o porte e as características da empresa. 
Por parte Conselho Nacional de Seguros Privados - CNSP, em relação ao "seguro de responsabilidade civil por danos causados ao meio ambiente ou à saúde pública", ainda não há regulamentação sobre regras de coberturas e demais especificidades. A redação da LPNRS, por outro lado, embora mais específica, todavia não permite inferir, com precisão, o que sejam os "danos causados ao meio ambiente ou à saúde pública". Esse ponto remete à problematização sobre as dimensões dos danos ambientais ${ }^{4}$ e suscita novamente as questões: a expressão "danos causados ao meio ambiente" compreende "meio ambiente" de forma ampla ou restringe-se aos dados ecológicos? Quando se refere à saúde pública, refere-se ao sentido difuso ou à tutela individual?

O tema ainda pode se tornar mais problemático. A análise de outra norma que institui um "seguro ambiental" - Lei Estadual 13.577/2009 do Estado de São Paulo - reitera os questionamentos acima apresentados.

Estado de São Paulo, desde 2009, possui legislação que trata da "proteção da qualidade do solo contra alterações nocivas por contaminação, da definição de responsabilidades, da identificação e do cadastramento de áreas contaminadas e da remediação dessas áreas". Contém previsão expressa sobre "seguros ambientais" como modalidade de instrumento para a implantação do sistema de proteção da qualidade do solo e para o gerenciamento de áreas contaminadas, no inciso $\mathrm{X}$ do artigo $4^{\circ} \mathrm{da}$ aludida lei. Tal norma foi regulamentada pelo Decreto 59.263/2013.

Tanto a Lei quanto o Decreto definem "seguro ambiental" como um dos seus instrumentos (artigo $4^{\circ}$, inciso X) para a implantação do sistema de proteção da qualidade do solo e para o gerenciamento de áreas contaminadas $^{5}$ e, nas definições apresentadas pelo mencionado decreto, o inciso XXXIII do artigo $3^{\circ}$ estabelece:

Seguro ambiental: contrato de seguro que contenha cobertura para assegurar a execução de Plano de Intervenção aprovado em

$4 \quad$ Vide, dentre outros, LEITE, José Rubens Morato; AYALA, Patryck de Araújo. Dano Ambiental: do individual ao coletivo extrapatrimonial. São Paulo: Revista dos Tribunais, 2012; SENDIM, José de Souza Cunhal. Responsabilidade civil por danos ecológicos: da reparação do dano através de restauração natural. Coimbra: Coimbra Editora, 1998; STEIGLEDER, Annelise Monteiro. Responsabilidade civil ambiental: as dimensões do dano ambiental no direito brasileiro. Porto Alegre: Livraria do Advogado, 2004.

5 A exigibilidade de tal instrumento, no entanto, está condicionada à disponibilização de produto específico pelo mercado segurador, conforme disposto no artigo $45, \S 1^{\circ}$, verbis: "O instrumento a que se refere o inciso X do artigo $4^{\circ}$ da Lei $n^{\circ} 13.577$, de 8 de julho de 2009, somente será exigido quando houver disponibilidade desse produto no mercado de seguros". 
sua totalidade e nos prazos estabelecidos, no valor mínimo de $125 \%$ (cento e vinte e cinco por cento) do custo estimado.

O artigo 45 do Decreto em apreço prevê a necessidade de apresentação de garantias (garantias bancárias ou seguro ambiental), a fim de assegurar o Plano de Intervenção, nos seguintes termos:

Artigo 45 - O responsável legal pela área contaminada deverá apresentar uma das garantias previstas nos incisos IX e X do artigo $4^{\circ}$ da Lei $n^{\circ} 13.577$, de 8 de julho de 2009, a fim de assegurar que o Plano de Intervenção aprovado seja implantado em sua totalidade e nos prazos estabelecidos, no valor mínimo de $125 \%$ (cento e vinte e cinco por cento) do custo estimado no respectivo Plano.

O "Plano de Intervenção" a que se faz referência é um instrumento aprovado pelo respectivo órgão ambiental e que servirá de guia para a implementação de processos de reabilitação de áreas contaminadas ${ }^{6}$, sendo claro que a recuperação de áreas contaminadas é justamente o foco principal da referida lei estadual. Tal decreto traz interessante ressalva, ao dispor que "poderá ser apresentado seguro-garantia em substituição às garantias a que se refere o caput deste artigo". Ou seja, na literalidade, prevê a possibilidade de oferecimento de seguro-garantia em substituição ao seguro ambiental.

Note-se, portanto, que, a partir de uma previsão vaga na LPNMA sobre "seguro ambiental", a LPNRS trata de um "seguro de responsabilidade civil por danos causados ao meio ambiente ou à saúde pública", enquanto a lei paulista trata de um "seguro ambiental" que poderá ser substituído por um seguro-garantia. A Lei 11.284/2006, que trata da gestão de florestas públicas, utiliza expressões análogas.

Importa mencionar, ainda que brevemente, que, além das normas vigentes, são frequentes propostas legislativas que busquem a instituição

\footnotetext{
6 Na forma do inciso II do artigo 3o entende-se por "Área Contaminada: área, terreno, local, instalação, edificação ou benfeitoria que contenha quantidades ou concentrações de matéria em condições que causem ou possam causar danos à saúde humana, ao meio ambiente ou a outro bem a proteger". A lei prevê ainda, no artigo $8^{\circ}$, as diversas classes de áreas contaminadas: I-Área com Potencial de Contaminação (AP); II-Área Suspeita de Contaminação (AS); III-Área Contaminada sob Investigação (ACI); IV-Área Contaminada com Risco Confirmado (ACRi); V-Área Contaminada em Processo de Remediação (ACRe); VI-Área em Processo de Monitoramento para Encerramento (AME); VII-Área Contaminada em Processo de Reutilização (ACRu); VIII-Área Reabilitada para o Uso Declarado (AR); IXÁrea Contaminada Crítica (AC crítica).
} 
de seguros ambientais, geralmente sugerindo a instituição de seguros ambientais obrigatórios?

Evidenciada a intenção reiterada do legislador de instituição de seguros ambientais, de seguros garantia ou de seguros de responsabilidade civil, são pertinentes os questionamentos: qual o objetivo da inserção de mecanismos de garantia em normas de proteção ambiental? Quem é o destinatário da garantia pretendida? Se as respostas indicarem a criação de instrumentos de garantia de reparação de danos a interesses da coletividade, ou a reparação de danos ecológicos, resta saber se os seguros são, de fato, a melhor forma de atender tais anseios. Em caso positivo, há que ponderar sobre o modelo de seguros pretendido. A imprecisão conceitual e a absoluta falta de clareza sobre a abrangência e objetivo do seguro proposto marcam todas as normas analisadas. Não há precisão sequer sobre o risco que se pretende seja coberto pelo "seguro ambiental" ventilado.

A partir dos elementos problematizados até este ponto, objetiva-se com o presente estudo promover a fixação de bases conceituais sobre os seguros, nos seus aspectos técnicos e jurídicos, sobre os riscos ambientais asseguráveis; e sobre os seguros ambientais, abordando suas diversas modalidades e formas de atuação, de modo a propiciar um desenvolvimento mais linear, claro e progressivo para esse instrumento econômico de garantia de reparação de danos ao meio ambiente.

\section{ATIVIDADE E TÉCNICA SEGURADORA PELA DISPER- SÇÃO DOS RISCOS: ESSENCIALIDADE E ORIGENS}

Os seguros surgiram da necessidade humana de proteção contra acontecimentos imprevisíveis (riscos) que resultam em perdas, sejam de valores materiais ou imateriais. Sua origem está associada às atividades de transporte de mercadorias e ao risco envolvido: raramente os

\footnotetext{
$7 \quad$ Outro exemplo de proposta de seguros ambientais está prevista no Projeto de Lei 3.729/2004, que objetiva instituir a Lei Geral de Licenciamento Ambiental. Tal PL prevê (no artigo $9^{\circ}$ da proposta de redação), que "caso sejam adotadas pelo empreendedor novas tecnologias, programas voluntários de gestão ambiental ou outras medidas que comprovadamente permitam alcançar resultados mais rigorosos do que os padrões e critérios estabelecidos pela legislação ambiental, a autoridade licenciadora poderá, motivadamente, estabelecer condições especiais no processo de licenciamento ambiental", tais como: redução de prazo de análise, dilação de prazos de renovação, simplificação do procedimento ou outras medidas. Estipula, ainda, no parágrafo único, que "as medidas previstas no caput poderão ser estendidas, com justificativa técnica, para atividades ou empreendimentos que: I - possuam seguros, garantias ou fianças ambientais quando do requerimento das licenças ambientais.
} 
patrimônios individuais podiam suportar os prejuízos decorrentes dos riscos dessa atividade. A base para o surgimento e desenvolvimento dos seguros foi a percepção de que se fazia necessária uma ação de forma comum entre os diversos envolvidos e praticantes da atividade de transportes - com sentido comunitário, portanto.

De fato, "como o nosso sistema de direito privado conserva-se ligado às fontes romanas, que concebiam o direito com uma relação rigorosamente bilateral, é compreensível que o contrato haja desempenhado um papel fundamental na destruição do comunitarismo medieval". A "atitude na ação social - no caso particular ou em média ou no tipo puro - repousa no sentimento subjetivo dos participantes de pertencer (afetiva ou tradicionalmente) ao mesmo grupo" 8 . Embora se atribuam às práticas mutualistas a origem dos seguros, o mutualismo, na realidade, é apenas uma técnica (exitosa) para lidar com os riscos, sendo certo que outras técnicas de dispersão do risco eram aplicadas ${ }^{9}$ - ainda que, em um primeiro momento, não seja possível denominar tais práticas propriamente como securitárias ${ }^{10}$. Assim, para alguns, a origem dos seguros remonta à antiguidade, ainda que em tal época estes institutos fossem apenas remotamente comparáveis aos seguros de hoje ${ }^{11}$.

8 BAPTISTA DA SILVA, Ovídio A. O seguro e as sociedades cooperativas: relações jurídicas comunitárias. Porto Alegre: Livraria do Advogado, 2008, p 8.

9 Segundo Cordeiro, "vários esquemas conseguiam, na prática, uma dispersão do risco. Mas não se apurou um tipo negocial que, de modo expresso e assumido, a isso se destinasse". CORDEIRO, António Menezes. Direito dos Seguros. Coimbra: Almedina, 2016, p. 59.

10 Conforme narra Luhmann, "En el antiguo comercio marítimo oriental existía ya una conciencia del riesgo, con las disposiciones legales correspondientes. En un comienzo éstas eran difícilmente separables de programas adivinatorios, invocación a deidades protectoras, etc. Sin embargo, en lo legal, en especial en la división de funciones de los prestadores de capital y los navegantes, hacían claramente las veces de aseguradoras, un papel que habría de extenderse de manera relativamente continua hasta ya entrada la Edad Media e influir en la conformación del derecho comercial marítimo, así como en los seguros de este tipo". LUHMANN, Niklas. Sociología del riesgo. Coord. Tradución Javier Torres Nafarrate. México D.F.: Universidad Iberoamericana, 2006, p. 53. Em complementação - inclusive para frisar a hipótese (uma delas) de que foram nas práticas comerciais e de seguros que teve origem a expressão 'risco', vale referir que "Los contextos importantes em los que se aplica [la palabra riesgo] son los de la navegación marítima y los contextos comerciales. Los seguros marítimos constituyen un caso temprano de control de riesgo planificado, pero también e independientemente de esto se encuentra en los contratos cláusulas como 'adrisicum et fortunam...', 'pro securitate et risico', o 'ad omnem risicum, periculum et fortuna Dei', que regulan quién ha de hacerse cargo de las reparaciones en el caso de que hubiera un daño". Idem, p. 54.

11 Neste sentido consultar, dentre outros, CORDEIRO, António Menezes. Direito dos Seguros. Coimbra: Almedina, 2016, p. 49 e seguintes, bem como PASQUALOTTO, Adalberto. Garantias no Direito das Obrigações: um ensaio de sistematização. Tese (Doutorado em Direito) - Faculdade de Direito, Universidade Federal do Rio Grande do Sul. Porto Alegre, 2005, p. 187. 
Na experiência romana, a existência de uma figura comparável à do seguro pressupõe uma observação contextualizada, pois, a rigor, em tal período não havia instituto que se assemelhasse aos seguros como compreendidos na atualidade. O fator risco era uma constante vinculada às práticas comerciais: se, então, havia expressiva atividade mercantil, isso implicava operações de compra, venda e transporte de mercadorias pela navegação; para viabilizar tais atividades, era comum o uso de empréstimo ou mútuo. Havia, assim, a noção de risco (periculum) e a possibilidade de dar cobertura aos acidentes nas atividades comerciais, ou, em outros termos, a possibilidade e o interesse na transferência e na pulverização do risco - uma forma de compartilhamento ${ }^{12}$.

Essa referência à experiência romana visa frisar que, se, na Idade Média, usaram-se técnicas para transferência e compartilhamento de riscos e para auferir ganho sobre os mesmos, não se pode negar que houve expressivo desenvolvimento de institutos relacionados à modulação do risco nesse período. Destaca-se, portanto, que o desenvolvimento das técnicas de enfrentamento dos riscos decorrido no período medieval seguiu um legado acumulado pelos romanos.

$\mathrm{Na}$ Idade Média, ocorre um salto no desenvolvimento dos seguros, com o aparecimento de formas originárias de mecanismos e conceitos que estão na essência do instituto até a atualidade. Foram inicialmente desenvolvidos pelos costumes e práticas comerciais para, em um segundo momento, receberem tratamento doutrinário e normativo. Durante a Idade Média "o seguro veio a surgir, em duas frentes muito distantes: a assistencial e a negocial, também chamada de seguro a prêmio"13.

O desenvolvimento crescente do transporte marítimo, ao necessitar do aporte de recursos, fez com que os operadores passassem a substituir o contrato de empréstimo por uma espécie inédita de contrato de compra e venda, pelo qual o comerciante transmitia a propriedade do bem (a embarcação e a carga) ao suposto comprador, mas esse só realizava o pagamento em caso de sinistro ${ }^{14}$, havendo, outrossim, uma cláusula resolutória para o caso de o transporte não ser concluído com a chegada ao porto de destino ${ }^{15}$.

12 PERANDONES, Pablo Girgado. El principio indemnizatorio en los seguros de daños: una aproximación a su significado. MERCATURA - Coleción Estudios de Derecho Mercantil n. 19. Granada: Comares, 2005, p. 12-18.

13 CORDEIRO, António Menezes. Direito dos Seguros. Coimbra: Almedina, 2016, p. 59. 14 BRIYS, Eric; VARENNE, François de. Assurance et marches financiers: concurrence ou complémentarité? Em EWALD, François; LORENZI, Jean-Hervé. Encyclopédie de l'assurance. Paris: Economica, 1998, p. 1666-1681.

15 PERANDONES, Pablo Girgado. El principio indemnizatorio en los seguros de daños: 
É correto afirmar que o seguro, então, funcionava como uma técnica de diluição do risco entre um coletivo de comerciantes, não se tratando, por si só, de uma atividade comercial propriamente dita. A evolução do instituto, porém, transformou-o progressivamente em um tipo comercial, ainda que o tenha acompanhado a noção comunitária (hoje compreendida como mutualismo). Desenvolveu-se um mecanismo de transferência dos riscos individuais a um administrador, que formava e gerenciava um fundo comum, integrado pelas contribuições individuais pagas pelos segurados, capaz de indenizar aqueles do grupo eventualmente atingidos por um evento danoso. Assim, o prejuízo individual era repartido pela coletividade comum.

Aos poucos, produziu-se um refinamento do instituto do seguro por meio de mecanismos como o princípio indenizatório, a repartição de riscos, a delimitação de critérios para fixação do prêmio, o estabelecimento de franquias, a estimação prévia de indenização e o recurso ao princípio da boa-fé ${ }^{16}$. Diversos institutos começaram a ser desenvolvidos, todavia visando evitar o enriquecimento indevido por meio do seguro e a localização do interesse como seu elemento.

Foi apenas no século XX que a prática de seguros se desvinculou do comércio rotineiro e ganhou autonomia negocial, passando a ser gerida por empresas (empresarialidade) e assumindo a capacidade e os métodos formais de gestão dos riscos ${ }^{17}$ e originando as grandes companhias seguradoras da atualidade ${ }^{18}$.

A teoria geral do risco indica que esse varia conforme as percepções: o que é risco para alguns, pode não ser para outros. Desse modo, um

una aproximación a su significado. MERCATURA - Coleción Estudios de Derecho Mercantil n. 19. Granada: Comares, 2005, p. 31-32.

16 PERANDONES, Pablo Girgado. El principio indemnizatorio en los seguros de daños: una aproximación a su significado. MERCATURA - Coleción Estudios de Derecho Mercantil n. 19. Granada: Comares, 2005, p. 32-39.

17 MONTI, Alberto. Environmental risks and insurance: a comparative analysis of the role of insurance in the management of environment-related risks. OCDE, 2002. Disponível em: <www.oecd.org/finance/financial-markets/1939368.pdf>. Acesso em: 18 nov. 2017, p. 5. Sobre as diferentes perspectivas de percepção e convivência com os riscos, afirma o autor que "Economic actors have different attitudes towards risks. It depends on several factors, including the nature of the risk, the probability of loss, the potential magnitude of the loss and the ability to absorb its economic consequences. Assuming rationality and perfect information, economic actors are able to calculate the actual value of a given risk by discounting the magnitude of the loss by the probability of its occurrence (PxL)".

18 PASQUALOTTO, Adalberto. Garantias no Direito das Obrigações: um ensaio de sistematização. Tese (Doutorado em Direito) - Faculdade de Direito, Universidade Federal do Rio Grande do Sul. Porto Alegre, 2005, p. 188. 
particular, diante de uma determinada ameaça, na sua vida ou no seu negócio, definirá se aceita ou não correr determinado risco. Aceitando-o, poderá optar por suportá-lo sozinho (autosseguro) ${ }^{19}$ ou transferi-lo, havendo, de fato, diversos mecanismos para tal transferência e pulverização, além dos seguros.

O mutualismo, por exemplo, é uma forma de dispersão dos riscos, pela qual o risco de um é fragmentado entre o risco de muitos. Como explica POLIDO:

O caráter mutual do seguro é preponderantemente, insiste-se, em razão de sua natureza comunitária. Não haveria seguro se apenas um ou meia dúzia de riscos fossem subscritos, uma vez que as apólices consideradas nesse universo não consubstanciariam a atividade seguradora em toda a sua acepção técnica e jurídica. [Para instituição de seguros, exige-se] volume substancial de riscos homogêneos, tecnicamente calculados e com prêmios representativos do custo real dos riscos assumidos pelo seu tomador. Esse volume de negócios forma o fundo garantidor do pagamento dos sinistros que sucederão ${ }^{20}$.

O mutualismo dispersa riscos, portanto, porque, em caso de sinistros, a soma de contribuições arcará com os prejuízos individuais. Assim, é pela pulverização dos próprios riscos em uma grande comunidade social que se dá suporte e segurança técnica para a própria atividade de seguros ${ }^{21}$.

Outra forma de realizar a dispersão ocorre quando o segurador divide com o próprio segurado a responsabilidade sobre o risco, limitando o início de sua responsabilidade. Essa fragmentação ocorre pelo esquema de franquias ou de participação obrigatória do segurado, pelo qual ao segurado se atribui a primeira responsabilidade sobre as perdas.

Pelo cosseguro, verificada a necessidade de pulverizar o risco, forma-se uma estrutura constituída por companhias seguradoras alinhadas (pool),

19 Pelo auto-seguro, um "potencial segurado, em vez de ajustar um contrato de seguro com uma seguradora, faz o seu próprio seguro, nomeadamente provisionando uma verba para acudir a eventuais prejuízos". MARTINEZ, Pedro Romano. Direito dos Seguros: apontamentos. S. João do Estoril: Principia, 2006, p. 63-64.

20 POLIDO, Walter. Contrato de seguro: novos paradigmas. São Paulo: Roncarati, 2010, pp. 93-94.

21 BAPTISTA DA SILVA, Ovídio A. O seguro e as sociedades cooperativas: relações jurídicas comunitárias. Porto Alegre: Livraria do Advogado, 2008, p. 69. 
na qual cada uma, proporcionalmente, haverá de receber o prêmio pago pelo segurado e, consequentemente, assumirá a responsabilidade pela importância segurada equivalente à sua cota de prêmio auferida ${ }^{22}$.

Por fim, quanto à dispersão de riscos, seguradores valem-se da transferência pela via do resseguro, assim definido por Polido:

O resseguro é uma forma seguradora de segundo grau, em que, através das diversas modalidades, as entidades seguradoras procuram homogeneizar e limitar as suas responsabilidades, para normalizar o comportamento da carteira de riscos assumidos, por meio da cobertura dos desvios ou desequilíbrios que afetem a frequência, a intensidade, a distribuição temporal ou o valor individual dos sinistros que a afetarem"23.

Como explica ALVAREZ, o resseguro é um mecanismo de partilha do risco adotado para dispersar o risco do segurador. Esclarece, recorrendo à lição de Paulo Luiz de Toledo Piza:

No âmbito securitário, a Teoria da Assunção de Risco implica a apreensão de uma unicidade da estrutura e da funcionalidade no contrato de resseguro, independentemente da forma ou modalidade técnica considerada, revelando a sua função precípua como garantidor da "proteção e viabilização do próprio exercício da atividade securitária". [...] o resseguro se constitui em "fator de produção do seguro", pelo qual "se reduzirá um risco do segurador, qual seja, o de ter de responder por eventual incorreção na repartição mutualística dos riscos segurados a que se volta”. Em outros termos, o resseguro reduz o risco que recai sobre o segurador, o segurado fica a salvo de novas contribuições a serem fixadas para tratar de resultados negativos oriundos dos desvios e desequilíbrios aos quais o seguro está sujeito ${ }^{24}$.

22 Dispõe o Código Civil, no artigo 761, que "quando o risco for assumido em co-seguro, a apólice indicará o segurador que administrará o contrato e representará os demais, para todos os seus efeitos". Nos termos do artigo 2, inciso II, da Lei Complementar 126/2007, "co-seguro: operação de seguro em que 2 (duas) ou mais sociedades seguradoras, com anuência do segurado, distribuem entre si, percentualmente, os riscos de determinada apólice, sem solidariedade entre elas".

23 POLIDO, Walter. Resseguro: cláusulas contratuais e particulares sobre responsabilidade civil. $2^{a}$ ed. Rio de Janeiro: Funenseg, 2011, p. 6.

24 ALVAREZ, Ana Maria Blanco Montiel. Resseguro e seguro: pontos de contato entre negócios jurídicos securitários. Porto Alegre: Livraria do Advogado, 2014, p. 104. 


\section{ATIVIDADE E TÉCNICA SEGURADORA PELA DELIMI- TAÇÃO DOS RISCOS}

A percepção e a definição de riscos asseguráveis depende do contexto compreensivo delimitado pela técnica seguradora. Isso envolve quatro pontos principais de avaliação do risco em questão, a saber: "sua natureza; a probabilidade de ocorrência; a característica da população que está exposta a ele; e a magnitude de suas consequências" 25 . Note-se que o risco assegurável pouco tem em comum com os riscos em sentido sociológico ou com os riscos ambientais.

Como observa ALVAREZ, discorrendo sobre o risco como negócio securitário, dois pontos são relevantes: "que a ocorrência do evento não necessariamente será futura, podendo ser presente e atual, ou mesmo pretérita" e, que "o risco não se relaciona com a incerteza individual, pois o risco é um dado social objetivo, e, portanto, deve estar relacionado com uma incerteza objetiva, consubstanciada na possibilidade de um acontecimento real" ${ }^{26}$. Por conseguinte, pontua:

O risco do negócio securitário precisa, outrossim, ser segurável tecnicamente e juridicamente [...]. Para ser segurável, requer: (i) possibilidade de ocorrência de um evento; (ii) incerteza da ocorrência de tal evento; por consequência da incerteza, (iii) involuntariedade quanto à ocorrência; e (iv) licitude, porquanto o risco deve se relacionar a interesse lícito ${ }^{27}$.

Para os seguros, enquanto atividade econômica, a possibilidade de atribuir valor a um risco é da sua essência. Como observa VEIGA COPO:

Previsibilidade, possibilidade, probabilidade e evitabilidade são constantes, mas também um cálculo, uma magnitude. Pesar e redistribuir esse risco, calibrando-o e permeando-o, é essencial no e para o contrato de seguro, pois as contingências são as possibilidades de verificar ou não o risco delimitado que, definitivamente, traça a fronteira ou fronteiras do risco ${ }^{28}$.

25 PEREIRA, Fernanda. Fundamentos técnicos - atuariais do seguro. In: MIRAGEM, Bruno; CARLINI, Angélica. Direito dos seguros: fundamentos de direito civil, direito empresarial e direito do consumidor. São Paulo: Revista dos Tribunais, 2014, pp. 36-38.

26 ALVAREZ, Ana Maria Blanco Montiel. Resseguro e seguro: pontos de contato entre negócios jurídicos securitários. Porto Alegre: Livraria do Advogado, 2014, pp. 103-104.

27 ALVAREZ, Ana Maria Blanco Montiel. Resseguro e seguro: pontos de contato entre negócios jurídicos securitários. Porto Alegre: Livraria do Advogado, 2014, p. 104.

28 VEIGA COPO, Abel B. El riesgo en el contrato de seguro: ensayo dogmático sobre el riesgo. Cizur Menor (Navarra): Aranzadi, 2015, p. 25. Tradução livre, do original em espanhol. 
O patamar atual dos seguros como prática de negócios pressupõe a capacidade de empresas especializadas, dotadas de técnicas de gestão de riscos, de anteverem os mesmos ${ }^{29}$ e de definirem seus escopos e dimensões, com tipologias e possibilidades de sua determinação. Afinal, racionalizar sobre

[...] o que, o quem, o como, o quando, o quanto, onde ocorrem, configuram e delimitam o risco efetivo que o contrato de seguro traça e o segurador cobre. Definir e delimitar. Incluir e excluir, evitando o esvaziamento do contrato e do risco ou, dito de outro modo, evitar a desnaturalização do contrato de seguro é o objetivo, mas também a essência do risco e por extensão do contrato de seguro ${ }^{30}$.

Para ressaltar a tecnicidade inerente à operação securitária, cuja conformação deve estar retratada no conteúdo do contrato de seguro, é relevante consignar que:

A operação asseguradora se desenvolve em forma técnica e a aproximação a seus resultados depende da estatística, do cálculo de probabilidade, da lei dos grandes números, do desvio médio de sinistralidade, da máxima perda provável, da medição da frequência dos acidentes, da severidade e da sua correlação com o preço adequado a cobrar ${ }^{31}$.

29 Para antever riscos, o segurador se vale, dentre outros mecanismos, da Lei dos Grandes Números, assim explicada por Colombo: "Em 1692, Jacob Bernoulli demonstrou o seguinte teorema: quando se conhece a probabilidade de ocorrência de um evento num experimento aleatório, é possível indicar quais são as expectativas da frequência da sua ocorrência, se o mesmo experimento for repetido um número considerável de vezes sob condições semelhantes. Por outro lado, se a probabilidade de um evento é desconhecida, mas o número de experimentos é muito grande, a sua probabilidade pode ser aproximada. (...) A frequência relativa de um evento é definida como a relação entre o número de vezes que um evento aconteceu numa dada série de repetições de um experimento aleatório e o número total de repetições do referido experimento. [...] numa série imensa de experimentos, a frequência relativa de um evento se aproxima cada vez mais da sua probabilidade. Em outras palavras, quando se repete um experimento um número suficientemente grande de vezes é possível, na equação apresentada, substituir a expressão 'frequência relativa' por 'probabilidade' com erro desprezível. Assim, dada uma longa série de experimentos, pode-se calcular a probabilidade de um evento". COLOMBO, Angelo. Contrato de seguros: limites técnicos de negociação entre seguradora e segurado. In: SCHALCH, Debora (org.). Seguros e resseguros: aspectos técnicos, jurídicos e econômicos. São Paulo: Saraiva/Virgília, 2010, pp. 29-30.

30 VEIGA COPO, Abel B. El riesgo en el contrato de seguro: ensayo dogmático sobre el riesgo. Cizur Menor (Navarra): Aranzadi, 2015, p. 20. Tradução livre, do original em espanhol.

31 PRIETO, Hilda Esperanza Zornosa. Escritos sobre riesgos y seguros. Bogotá: Universidad Externado de Colombia, 2012, p. 585. Tradução livre, do original em espanhol. 
A atividade seguradora pressupõe, no processo de transferência e aceitação do risco, um exercício constante e qualificado de delimitação do risco que estará sendo aceito e que passará a ser coberto pelo segurador. Veiga Copo propõe as seguintes tipologias de delimitação: extensão objetiva, extensão subjetiva, extensão espacial, extensão quantitativa e extensão temporal, afirmando que

A determinação do risco segurado requer uma tarefa de dissecação prévia, individualização do risco através da naturalização do evento e do interesse sobre o qual ele cai, assim como, finalmente, sua delimitação causal, espacial e temporal. Entramos no campo estrito, mas necessário, do exame do nexo entre causa e evento, mas também em uma análise mais ampla, o elo etiológico entre evento e dano; e se esse evento foi descrito, individualizado, incluído no escopo do risco assumido e segurado, o evento ocorrido, causando dano ou não, esteja excluído da cobertura e assunção pela seguradora ${ }^{32}$.

Antes de analisar essas diversas formas de delimitação dos riscos, é necessário referir o tênue limite, aqui tratado em termos contratuais, entre a delimitação de riscos no contrato de seguro e as cláusulas limitativas de diretos. Se a delimitação de riscos é necessária, é fundamental que seja coerente e racional para ser legítima ${ }^{33}$.

A delimitação objetiva dos riscos se dá pelo exercício material e formal de definição, com precisão, do que sejam riscos cobertos e riscos excluídos do seguro. Afinal,

A delimitação do risco na apólice ou nas condições deve partir de uma premissa, definição e delimitação objetivas conclusivas. Objetividade e neutralidade no próprio núcleo, na essência da cobertura causal. [...] O que é coberto e o que é excluído requer clareza, precisão e definição ${ }^{34}$.

Em complementação,

A delimitação objetiva significa materialmente e objetivamente especificar aqueles bens, objetos, coisas, patrimônio, vida, saú-

32 VEIGA COPO, Abel B. El riesgo en el contrato de seguro: ensayo dogmático sobre el riesgo. Cizur Menor (Navarra): Aranzadi, 2015, p. 309-310. Tradução livre, do original em espanhol.

33 VEIGA COPO, Abel B. El riesgo en el contrato de seguro: ensayo dogmático sobre el riesgo. Cizur Menor (Navarra): Aranzadi, 2015, p. 311.

34 VEIGA COPO, Abel B. El riesgo en el contrato de seguro: ensayo dogmático sobre el riesgo. Cizur Menor (Navarra): Aranzadi, 2015, p. 311. Tradução livre, do original em espanhol. 
de, etc. que são e serão objeto do contrato de seguro específico, seja de danos ou de pessoas, ou assistência. As coberturas específicas e garantias que se enquadram neste seguro são definidas de forma rigorosa e específica. Configurar, direta e indiretamente, a hipótese ou hipóteses de sinistro.

Uma delimitação material ou objetiva do risco que define,especifica, mas também pode excluir a cobertura de risco ${ }^{35}$.

A questão da delimitação objetiva, portanto, não é outra coisa senão a clarificação imediata do escopo de um determinado seguro, ou seja, a definição da atividade contemplada, para compreensão dos riscos que lhe são próprios. Tendo clareza de quais sejam os riscos, definem-se as respectivas coberturas e, ao contrário, tão importante quanto, os riscos que não serão cobertos, chamados de riscos excluídos (seja por opção do segurador ou do próprio segurado).

A delimitação pelos seguros envolve a definição de quem sejam o segurado e os beneficiários do seguro. Trata-se de delimitação subjetiva no contrato de seguro, sobre a qual discorre VEIGA COPO:

A delimitação subjetiva implica especificar a pessoa ou as pessoas determinadas sobre quem recai o seguro, tanto em seus atos e comportamentos quanto na própria pessoa em si. Cláusulas e delimitações que determinam e especificam nomeadamente os segurados, seja a quem corresponda ou com determinabilidade no futuro, seja por determinações genéricas como 'terceiro', 'familiares', 'empregados', 'dependente', etc.

Delimitação subjetiva onde a atitude e o comportamento do segurado e das pessoas que dependem dele prefiguram e acabam configurando a cobertura ou não do risco por parte da seguradora ${ }^{36}$.

Significa dizer que os seguros cobrem riscos gerados pela atividade do próprio segurado ou daqueles outros nomeados no contrato de seguro que ajam em seu nome ${ }^{37}$. Jamais cobrirá riscos ou arcará com indeni-

35 VEIGA COPO, Abel B. El riesgo en el contrato de seguro: ensayo dogmático sobre el riesgo. Cizur Menor (Navarra): Aranzadi, 2015, p. 313. Tradução livre, do original em espanhol. 36 VEIGA COPO, Abel B. El riesgo en el contrato de seguro: ensayo dogmático sobre el riesgo. Cizur Menor (Navarra): Aranzadi, 2015, p. 344 e 347. Tradução livre, do original em espanhol. 37 Para exemplificar, nos contratos de seguros para riscos ambientais, com algumas variações, segurados são assim definidos: Segurado, significa o Segurado Nomeado, ou qualquer pessoa que é ou foi diretor, dirigente, sócio, membro ou empregado, inclusive empregados temporários ou terceirizados, do Segurado Nomeado, enquanto atuar no âmbito destas funções 
zações por danos ocasionados por qualquer um que não seja seu segurado. Embora isso seja óbvio, não é simples. Não é simples em razão de duas variáveis que, em matéria de responsabilidade civil ambiental, avultam em complexidade: (i) a responsabilidade decorrente de evento pluricausal ${ }^{38}$ e (ii) a questão de que o segurador, ao definir quem será ou quem serão seu(s) segurado(s), projeta as possibilidades de responsabilização ${ }^{39}$ daquele(s) para os riscos que ele, segurador, esteja assumido. Ao cogitar essas possibilidades de responsabilização, projeta um limite provável de perdas, ou seja, estima até onde poderá ir a responsabilidade civil ambiental de seu(s) segurado(s) no âmbito de suas atividades e nos limites do contrato de seguro. Isso é feito com base nas regras previstas no sistema jurídico. A questão ganha novos contornos e se converte em um problema complexo quando o sistema não é claro sobre qual será o limite de responsabilidade - pois o sistema jurídico tampouco explicita, de forma precisa, as circunstâncias que poderão fazer com que a responsabilidade recaia sobre os indivíduos. E dizer: quem poderá ser abrangido pelo conceito vago de "poluidor"?

De fundamental importância para os seguros é a questão da sua delimitação temporal, o que significa determinar o início e fim de sua vigência, mas, também, os efeitos das renovações e, mais além, a própria res-

como tal. Já como Segurado Nomeado, (i) a pessoa nomeada na apólice; e (ii) qualquer e todas as corporações, sociedades, empresas ou outras entidades que tenham existido a qualquer tempo, que existam atualmente ou que possam vir a existir durante o Período de Vigência da Apólice, sobre as quais a pessoa nomeada na apólice teve ou tenha (um determinado percentual das) quotas de participação, mas, a respeito de tais corporações, sociedades, empresas ou outras entidades, apenas no que for relativo a responsabilidade decorrente de propriedade, operações, manutenções ou uso de Propriedade(s) Segurada(s).

38 O evento pluricausal pode envolver mais de um agente nocivo/poluente e também mais de um agente poluidor. Trata-se de questão que afeta a (co)causalidade, na qual há cumulatividade de agentes poluentes/contaminantes, que podem ser caracterizados como efeitos somativos. Esses, por sua vez, podem ser compreendidos em duas distintas situações: os efeitos aditivos e os efeitos sinérgicos. Os efeitos somativos são aqueles que "apontam para alterações ambientais decorrentes do somatório de muitas quotas individuais provenientes dos simultâneos ou sucessivos efeitos industriais de mesma espécie", enquanto os efeitos aditivos, embora semelhantes aos somativos, distingam-se na medida em que "são aqueles que não se resumem a um problema de quantidade nem dos efeitos resultantes das mesmas formas de comportamento, sendo, antes, resultado de complexas conexões de quotas individuais de ações diversificadas". Já os efeitos sinérgicos têm a característica da exponencialidade e mutabilidade, ou seja, "relacionam-se à combinação de elementos e de substâncias diferentes no ambiente de forma que, quando se encontram, geram um efeito (em regra, nocivo) maior do que o somatório das mesmas substâncias quando isoladas". CAETANO, Matheus Almeida. Os delitos de acumulação no direito penal ambiental. São Paulo: Editora Pillares, 2016, pp. 218-219.

39 Dependendo da exposição verificada nesta projeção, poderá, inclusive, não aceitar dar cobertura, ou seja, não aceitar o risco e rejeitar fazer o seguro. 
ponsabilidade do segurador em período que extrapole, antes ou depois, a vigência do contrato. Como afirma VEIGA COPO,

Determinar o alcance da cobertura, seu início exato, a eficácia retroativa ou posterior da mesma, especialmente no seguro de responsabilidade civil, a incidência da dimensão tempo na taxa de prêmio, seu pagamento sucessivo ou periódico e as consequências do não pagamento e o tempo, o fracionamento do prêmio ao longo do tempo, a equivalência entre cobertura e prêmio durante a vigência do contrato, independentemente de ocorrer ou não uma perda, o tempo da perda, a reclamação, a exigibilidade, judicial ou não, são infinitos problemas da prática de $\operatorname{seguros}^{40}$.

A delimitação do tempo terá importância, ainda, para definir o período de retroatividade da apólice, quer dizer, a possibilidade de o seguro dar garantia para eventos ocorridos anteriormente ao início da sua vigência (desde que desconhecidos, necessariamente) - limites esses que devem estar claros e delimitados no contrato de seguro, destacadamente em face de riscos ambientais, que possuem peculiaridades muito próprias.

Seguros sempre funcionam com limites quantitativos. As coberturas e as indenizações serão limitadas de diversas formas, pois estão atreladas ao prêmio que, salvo exceções, será previamente estabelecido com base no risco que se pretende garantir. Há, por evidente, correlação entre prêmio e coberturas. Nos seguros de danos, há um limite elementar, vinculado ao princípio indenizatório e ao interesse segurado.

Pela delimitação quantitativa, como esclarece VEIGA COPO,

A soma segurada ou valor segurado encontra seu limite, por um lado, no interesse segurável, ou seja, o valor real do objeto ou bem segurado e, por outro lado, atua como limite para cada sinistro, quando uma coisa ou um bem, ou pessoa em caso de acidente ou assistência médica [...], a seguradora é obrigada a indenizar cada um deles - os sinistros - dentro desse limite específico. Regula-se, em suma, pelo princípio de indenização no seguro de danos que impede o enriquecimento do segurado. Este, como detentor do interesse segurado, recebe um equivalente no caso em que a compensação do prejuízo é pecuniária ou monetária, o prejuízo sofrido por seus ativos com a destruição da coisa ou objeto do contrato ${ }^{41}$.

$40 \quad$ VEIGA COPO, Abel B. El riesgo en el contrato de seguro: ensayo dogmático sobre el riesgo. Cizur Menor (Navarra): Aranzadi, 2015, p. 363. Tradução livre, do original em espanhol. 41 VEIGA COPO, Abel B. El riesgo en el contrato de seguro: ensayo dogmático sobre el riesgo. Cizur Menor (Navarra): Aranzadi, 2015, pp. 386-387. Tradução livre, do original em espanhol. 
Os limites quantitativos poderão ocorrer, ainda, por cobertura (para cada cobertura de um risco objetivamente delimitado), mas, também, por sinistro (LMI) ou mesmo para um limite máximo de garantia (LMG) e sempre estarão, em cada contrato, condicionados ao limite agregado, ou seja, ao valor máximo indenizável pelo contrato, em todos os sinistros, durante a sua vigência.

Outro exemplo de limitação quantitativa é a franquia ou participação obrigatória do segurado nos prejuízos ocorridos com o sinistro (instituto sobre o qual se discorreu anteriormente, situando-o também como forma de dispersão de risco).

A delimitação espacial refere-se à descrição e âmbito territorial de incidência do seguro, ou seja, o lugar ou os lugares em que está localizado o risco. Segundo VEIGA COPO,

Quanto às cláusulas de delimitação espacial ou geográfica, estas dependem em grande medida do tipo de risco envolvido. Neste campo terá que atender à natureza móvel ou imóvel da coisa segurada, de sua mobilidade ou não, de sua localização inicial e, finalmente, especialmente se mediou ou não o consentimento da seguradora para mover a coisa de um lugar para outro diferente do inicialmente declarado no contrato ${ }^{42}$.

A questão do lugar, para os seguros ambientais, é das mais complexas e relevantes. Pensando em um segurado que seja uma indústria, é necessário considerar a delimitação e a compreensão do lugar, do seu histórico, dos seus passivos, de outros tipos de atividades já realizadas no mesmo espaço, as demais indústrias localizadas proximamente, a existência de recursos naturais, bem como a qualidade destes recursos naturais, o perfil e quantidade de pessoas em comunidades e moradias próximas. Todos esses elementos serão de enorme importância para uma adequada compreensão e mensuração do risco.

Uma vez que a delimitação dos riscos, em suas diversas formas, possui acentuada influência na prática de seguros, uma variável que deve ser apreciada é a hipótese de variabilidade do risco, bem como os reflexos da alteração dos riscos para os seguros. Como explica ANDRADE,

O negócio jurídico de seguro deve manter uma correlação entre o prêmio e o risco contratados. Nesses termos, se houver um au-

42 VEIGA COPO, Abel B. El riesgo en el contrato de seguro: ensayo dogmático sobre el riesgo. Cizur Menor (Navarra): Aranzadi, 2015, p. 395. Tradução livre, do original em espanhol. 
mento da probabilidade de ocorrência do risco, esta circunstância pode afetar, de modo sensível, o referido equilíbrio contratual ${ }^{43}$.

Os riscos podem variar, inclusive durante a vigência do contrato, tanto por razões internas quanto por razões externas ao segurado, sendo tal variação possível tanto para o aumento quanto para a diminuição dos riscos. Quando isso ocorrer, decorrerá na obrigação do segurado de comunicar ao segurador as condições de alteração ${ }^{44}$. A comunicação do agravamento do risco tem o objetivo de preservar o equilíbrio contratual, de modo que a seguradora conheça e avalie a situação do risco real, objetivo, apropriado ao momento efetivo ${ }^{45}$. Por conseguinte, diante de uma situação de agravamento, o segurado perderá o direito à garantia se deixar de comunicar à seguradora sobre o incidente ou a situação relevante que possa interferir nesse equilíbrio.

\section{CLASSIFICAÇÃO DOS SEGUROS}

O desenvolvimento dos inúmeros tipos de seguros é uma construção decorrente das práticas e das necessidades sociais e econômicas. Conforme observa CORDEIRO,

As diversas modalidades de seguro surgiram, ao longo da História, de acordo com as necessidades da vida comercial. Primeiro acantonadas ao sector marítimo, elas vieram a alargar-se às pessoas e, depois, aos vários riscos terrestres. Não obedecem a qualquer plano de conjunto ou, sequer, de enquadramento: antes conheceram um desenvolvimento periférico, quiçá empírico ${ }^{46}$.

43 ANDRADE, Fábio Siebeneichler de. O desenvolvimento do contrato de seguro no direito civil brasileiro atual. Revista de Derecho Privado. Bogotá: Universidad Externado de Colombia, n. 28, enero-junio, 2015, p. 219.

44 Código Civil, art. 769. O segurado é obrigado a comunicar ao segurador, logo que saiba, todo incidente suscetível de agravar consideravelmente o risco coberto, sob pena de perder o direito à garantia, se provar que silenciou de má-fé. $1^{\circ} \mathrm{O}$ segurador, desde que o faça nos quinze dias seguintes ao recebimento do aviso da agravação do risco sem culpa do segurado, poderá dar-lhe ciência, por escrito, de sua decisão de resolver o contrato. 2ํㅡ A resolução só será eficaz trinta dias após a notificação, devendo ser restituída pelo segurador a diferença do prêmio. Código Civil, art. 770. Salvo disposição em contrário, a diminuição do risco no curso do contrato não acarreta a redução do prêmio estipulado; mas, se a redução do risco for considerável, o segurado poderá exigir a revisão do prêmio, ou a resolução do contrato.

45 VEIGA COPO, Abel B. El riesgo en el contrato de seguro: ensayo dogmático sobre el riesgo. Cizur Menor (Navarra): Aranzadi, 2015, p. 245.

46 CORDEIRO, António Menezes. Direito dos Seguros. Coimbra: Almedina, 2016, p. 791. 
Os diversos tipos de seguro poderão ser combinados, sendo possível encontrar contratos de seguro que reúnam várias características destas diversas classificações ${ }^{47}$. Importa-nos atentar para a definição de seguros de danos e de pessoas, passando pela compreensão do seguro garantia e pela distinção entre seguros obrigatórios e facultativos.

A diferenciação encontra amparo na legislação, especificamente no Código Civil brasileiro - os artigos 778 a 802 tratam de dois gêneros de seguros: os seguros de danos e os seguros de pessoas. Nessa divisão se encontram as bases para as derivações dos seguros a suas diversas espécies (ramos) disponibilizadas pelo mercado segurador.

O seguro de pessoas é o gênero que visa garantir ao segurado ou aos seus beneficiários o pagamento de determinada soma em dinheiro caso ocorra algum evento danoso capaz de afetar a vida ou a saúde do segurado. Ao contrário do seguro de dano, não tem natureza indenitária, pela razão de ser impossível aferir valores monetários à vida e à saúde humana. Por isso, os seguros de pessoas, a rigor, não apresentam um limite máximo de cobertura securitária. A quantia que eventualmente será devida pelo segurador, em caso de sinistro (valor do capital segurado), pode ser livremente estipulada pelo proponente do seguro ${ }^{48}$, admitindo-se até mesmo a contratação de mais de um seguro sobre o mesmo interesse $^{49}$, conforme dispõe o artigo 789 do Código Civil brasileiro ${ }^{50}$.

Por outro lado, os seguros de danos têm especial importância, pois é a partir desse gênero que se localizam a espécie e as subespécies dos seguros de responsabilidade civil. Diferentemente dos seguros de pessoas, esses detêm "natureza tipicamente indenitária, ou seja, são voltados à recomposição patrimonial do segurado, de modo que, ocorrendo o sinistro, o sujeito favorecido pela indenização deverá fazer prova dos prejuízos econômicos sofridos" $"$.

São seguros de danos todos aqueles de caráter indenitário, em que o interesse legítimo segurável, objeto do contrato, incide sobre um bem

47 VASQUES, José. Contrato de seguro: notas para uma teoria geral. Coimbra: Coimbra Editora, 1999, p. 55.

48 Nesse sentido, vide PERANDONES, Pablo Girgado. El principio indemnizatorio en los seguros de daños: una aproximación a su significado. MERCATURA - Colección Estudios de Derecho Mercantil, n. 19. Granada: Comares, 2005, e do mesmo autor, La póliza estimada: la valoración convencional del interés en los seguros de daños. Madrid: Marcial Pons, 2015.

49 SILVA, Ivan de Oliveira. Curso de direito do seguro. São Paulo: Saraiva, 2012, p. 220.

$50 \quad$ Código Civil, artigo 789: Nos seguros de pessoas, o capital segurado é livremente estipulado pelo proponente, que pode contratar mais de um seguro sobre o mesmo interesse, com o mesmo ou diversos seguradores.

51 SILVA, Ivan de Oliveira. Curso de direito do seguro. São Paulo: Saraiva, 2012, p. 213. 
economicamente apreciável, pelo qual se indeniza o prejuízo que o segurado efetivamente sofreu ${ }^{52}$. A finalidade é a recomposição patrimonial do segurado diante de uma perda que tenha experimentado, seja por danos aos próprios bens, seja pela perda patrimonial decorrente de uma obrigação para com terceiros, em razão de sujeição ao regime de responsabilidade civil.

Os seguros de danos dividem-se entre patrimoniais e de responsabilidade civil. Ambos servem ao objetivo de resguardo ou de reposição dos bens e do patrimônio do segurado. Nos patrimoniais, protegem-se seus bens diretos; nos de responsabilidade civil, a reposição patrimonial cumpre a obrigação de reparar algum dano causado a terceiros. Os seguros de danos, como os seguros em geral, servem ao segurado e aos seus interesses - a proteção de terceiros somente surgirá de maneira reflexa, como garantia, nas hipóteses de insuficiência ou de indisponibilidade do patrimônio pessoal do segurado.

O seguro de responsabilidade civil representa uma das diversas espécies do vasto campo de atuação dos seguros, consistindo em importante instrumento diante das atuais contingências da vida moderna ${ }^{\frac{53}{3}}$. Pode ser definido como aquele em que se obriga o segurador a indenizar terceiros, em conformidade com o previsto no contrato e dentro dos limites legais e contratuais, diante da condição de um segurado que esteja civilmente responsável por danos causados a outrem ${ }^{54}$. O Código Civil de 2002 estabelece um conceito legal para o seguro de responsabilidade civil: seu art. 787 dispõe que "no seguro de responsabilidade civil, o segurador garante o pagamento de perdas e danos devidos pelo segurado a terceiro".

O seguro de responsabilidade civil está vinculado ao interesse do segurado em manter seu patrimônio protegido contra o risco de ser-lhe imposta alguma responsabilidade; ou seja, busca no seguro a garantia de não precisar diminuir seu patrimônio em razão dos resultados civis negativos que venha a causar a outrem. $O$ risco coberto por essa classe de seguro é a eventualidade de ocorrência de danos a terceiros que sejam imputados ao segurado, de modo que tenha que responder por tais danos ${ }^{55}$.

52 BECHARA SANTOS, Ricardo. Direito de seguro no Código Civil e legislação própria. Rio de Janeiro: Forense, 2006, pp. 188-189.

53 FERREIRA SILVA, Rita Gonçalves. Do contrato de seguro de responsabilidade civil geral: seu enquadramento e aspectos jurídicos essenciais. Coimbra: Coimbra, 2007, p. 101.

54 BARBAT, Andrea Signorino. Los seguros de responsabilidad civil: caracteres generales y coberturas principales. Montevideo: Fundación de Cultura Universitaria, 2011, p. 55-56.

55 REGO, Margarida Lima. Contrato de seguro e terceiros: estudo de direito civil. Coimbra: Coimbra Editora/Wolters Kluwer, 2010, p. 646. A autora faz uma ressalva importante em relação ao que, no Brasil, denominamos de Custos de Defesa, uma cobertura largamente 
Alguns autores, como Ferreira DA SILVA, entendem que esse ramo vise, simultaneamente, resguardar o patrimônio do segurado (evitando que sofra diminuição ativa ou aumento passivo) e proteger os "legítimos interesses" dos terceiros lesados, cujos danos sofridos são ressarcidos pela seguradora ${ }^{56}$. Não há como negar, portanto, a possibilidade de atendimento de um compromisso com dimensão de ética social no seguro de responsabilidade civil. Os seguros de responsabilidade civil transmitem a ideia de dever social, pois "o plexo relacional de indivíduos, cada qual podendo causar danos e prejuízos a outro membro da coletividade e cada indivíduo lesado repercutindo o seu dano também a outras pessoas, necessita de garantia de indenização"57.

O seguro garantia é uma categoria particular de seguro, que tem sua origem nos seguros de crédito. O seguro de crédito, segundo Silva Santos, é

[...] um contrato pelo qual o segurador dá cobertura a um risco de não pagamento atempado ou a uma impossibilidade de pagamento por parte de um devedor - um terceiro - com quem o segurado, credor, contratou, sendo os tempos da prestação e da contraprestação, na relação obrigacional entre o segurado e terceiro, defasados entre $\mathrm{si}^{58}$.

Essa singular modalidade de seguro tem, claramente, função e natureza de caução, na medida em que o segurador, ao aceitar o risco do tomador, lhe dá capacidade de crédito $^{59}$, logo, de credibilidade. Por conseguinte, o seguro garantia serve como caução para o cumprimento de uma obrigação positiva, que pode ser de dar, de pagar ou de fazer ${ }^{60}$. A

presente nos seguros de responsabilidade civil, ainda que não se enquadre propriamente nessa categoria. Diz respeito a custos que possam incorrer ao segurado no exercício de sua defesa perante terceiros. Assinala a autora, neste sentido, que "deixo de fora a cobertura de despesas associadas à refutação de pretenções infundadas de terceiro por considerar que, ainda que estas se encontrem por vezes cobertas num seguro de responsabilidade civil, não o definem".

56 FERREIRA SILVA, Rita Gonçalves. Do contrato de seguro de responsabilidade civil geral: seu enquadramento e aspectos jurídicos essenciais. Coimbra: Coimbra, 2007, p. 105.

57 POLIDO, Walter. Contrato de seguro: novos paradigmas. São Paulo: Roncarati, 2010, p. 191.

58 SILVA SANTOS, Margarida. Seguro de crédito. Lisboa: Prime Books, 2004, p. 26. O seguro de crédito, portanto, vincula-se a outro contrato, ao qual presta garantia de satisfação do crédito, em caso de descumprimento pelo devedor, nas hipóteses (riscos) predefinidas.

59 ALMADA, Beatriz de Moura Campos Mello. O seguro garantia como mitigador de riscos nos grandes projetos. In: SCHALCH, Debora (org.). Seguros e resseguros: aspectos técnicos, jurídicos e econômicos. São Paulo: Saraiva/Virgília, 2010, p. 284.

60 Para VASQUES, "o seguro-caução garante, direta ou indiretamente, o risco de incumprimento ou atraso de cumprimento de obrigações que, por lei ou convenção, sejam susceptíveis de caução, fianca ou aval". VASQUES, José. Contrato de seguro: notas para uma teoria geral. Coimbra: Coimbra Editora, 1999, p. 72. 
expressão "seguro garantia", ou "seguro que serve de garantia", aparenta redundância, mas não é contraditória na sua essência. Esta teratologia aparente serve, ao contrário, para diferenciar a função e a natureza do seguro garantia em relação às outras - e mais conhecidas - modalidades de seguro, geralmente atreladas a "garantir" o patrimônio pessoal do segurado, tal como se dá nos seguros de danos.

A garantia desse tipo de seguro é prestada ao credor. Trata-se, portanto, de seguro à conta de outrem, no qual intervêm, necessariamente, três pessoas distintas: segurador, tomador e o terceiro beneficiário. A dinâmica obrigacional desenvolve-se do seguinte modo:

No seguro caução, existe um trilátero relacional, no primeiro lado o segurado e o segurador, no segundo o segurado e o seu credor e no terceiro a eventual relação entre o segurador e o terceiro beneficiário. Duas figuras distintas se encontram em relação com o segurador, o tomador, que subscreve e o terceiro, que recebe a eventual verba da indenização ${ }^{61}$.

Seguros facultativos, tal como explícito em sua nomenclatura, são aqueles de livre escolha e contratação pelo segurado. A opção pelos seguros, nesse caso, está a depender essencialmente do nível de compreensão sobre responsabilidade e prevenção que detenha certo indivíduo. Por evidente, quanto maior seu grau de consciência sobre previdência, $\mathrm{o}$ indivíduo estará mais apto e propenso a contratar seguros ou outras formas de resguardo. A opção pelos seguros, de forma facultativa, decorre, ainda, da maior ou menor propensão do indivíduo aos riscos; maior ou menor aversão a eles.

Os seguros obrigatórios são compulsórios por força de lei, sendo muito comum a instituição desse tipo de obrigação nos seguros de responsabilidade civil. Se anteriormente se afirmou que os seguros têm foco nos interesses e na proteção do segurado e de seu patrimônio, nos obrigatórios há uma alteração do foco, cuja preocupação está na proteção da coletividade, difusamente considerada. Trata-se, aqui, de situação destacada de cumprimento de uma função social pelos seguros, evidenciando-se o viés da solidariedade. Solidariza-se a obrigação de reparar os danos.

No Brasil, os seguros obrigatórios possuem previsão no artigo 20 do Decreto-Lei 73/1966. No que se refere aos seguros ambientais, embora não exista obrigatoriedade, resta clara certa carga de compulsoriedade segundo as leis analisadas no início desse estudo. 


\section{DEFINIÇÃO DO BENEFICIÁRIO DO SEGURO E REDI- MENSIONAMENTO DO TERCEIRO LESADO NA RESPON- SABILIDADE CIVIL AMBIENTAL}

Sinalizou-se anteriormente, em tópico sobre o conceito de seguro de responsabilidade civil, a posição do terceiro e a questão da definição do terceiro, para fins de compreensão da amplitude e dos beneficiários nos seguros de responsabilidade civil ambiental no âmbito dos riscos ambientais e das lesões difusas. Esta reflexão, com efeito, é da maior importância, pois afeta o redimensionamento do terceiro lesado na responsabilidade civil ambiental.

O seguro de responsabilidade civil ambiental não se cinge ao terceiro lesado de forma clara e diretamente identificável. Este universo é maior e admite uma gama de terceiros com possibilidades de pretensão em face do segurado, ainda que as causas sejam expressivamente diversas. Vale citar a exemplificação proposta por Rego:

[...] vítimas directas e indirectas, desde que titulares de um direito a uma indemnização, bem como quem nos seus direitos se haja sub-rogado, designadamente um segurador com quem tenham celebrado um seguro de coisas e que tenha avançado com a indemnização, ou um co-autor da lesão a quem tenha sido exigido o pagamento integral da indemnização, obrigação solidária, e finalmente quaisquer terceiros que se tenham envolvido no tratamento da lesão [...] e que sejam também titulares de um direito de ressarcimento pelos prejuízos sofridos ${ }^{62}$.

O terceiro reflexamente lesado não foge do escopo tradicional dos seguros de responsabilidade civil, contudo, se ponderarmos sobre a figura do terceiro diante dos danos ecológicos puros (dano ambiental em sentido estrito) e do dano ambiental difuso (extrapatrimonial) - e é nesta dimensão que se insere a inovação trazida pelos seguros ambientais -, sua figura, por um lado, fica imprecisa e, por outro, ampliada. Será imprecisa porque o terceiro difuso é absolutamente diverso do terceiro típico, singular, dos seguros de responsabilidade civil.

Este novo terceiro caracteriza-se pela "transindividualidade real ou essencial ampla"; pela "indeterminabilidade de seus sujeitos"; pela "indivisibilidade ampla"; pela "indisponibilidade no campo relacional ju-

62 REGO, Margarida Lima. Contrato de seguro e terceiros: estudo de direito civil. Coimbra: Coimbra Editora/Wolters Kluwer, 2010, pp. 651-652. 
rídico"; e pela "ressarcibilidade indireta". É ampliada - e isto parece perturbador - porque terceiros passam a ser toda a coletividade titular do direito ao meio ambiente ecologicamente equilibrado (o que inclui o próprio segurado-poluidor). Leite e Ayala, a partir de proposta de Benjamin $^{63}$, explicam estas peculiaridades:

1. "transindividualidade real ou essencial ampla", quando o número de pessoas ultrapassa a esfera de atuação dos indivíduos isoladamente considerados, para levá-la a uma dimensão coletiva. Outrossim esta transindividualidade real significa dizer que a pluralidade de sujeitos chega ao ponto de se confundir, muitas vezes, com a comunidade; 2 . "indeterminabilidade de seus sujeitos", isto é, as pessoas envolvidas são substancialmente anônimas; 3. "indivisibilidade ampla", ou seja, uma espécie de comunhão, tipificada pelo fato de que a satisfação de um só implica a satisfação de todos, assim como a lesão de um só constitui a lesão da inteira coletividade; 4. "indisponibilidade no campo relacional jurídico", por não dispor de titulares determináveis, apresenta dificuldades em transigir de seu objeto no campo jurídico-relacional; 5. pela "ressarcibilidade indireta", quando não houver a reparabilidade direta aos sujeitos considerados, (levando em conta o caráter 'anônimo' dos sujeitos) e, sim, ao fundo, para recuperação dos bens lesados ${ }^{64}$.

Um terceiro difuso, portanto, terá seus direitos e interesses tutelados e exigíveis não pelos tradicionais mecanismos de reclamação e acesso à justiça, de forma individual, mas pela técnica da tutela coletiva de direitos, manejáveis, especialmente pela via da Ação Civil Pública. Ele se faz representado pelos atores legitimados pela LACP ou por qualquer cidadão, pela via da Ação Popular, ocasião em que qualquer um deles estará capacitado para reclamar em nome de toda a coletividade. Considere-se, por conseguinte, a amplitude de uma única reclamação que tenha por escopo tutelar direitos difusos e coletivos.

A questão é de relevância e para tal o setor de seguros deve atentar, pois rompe significativamente com a lógica segundo a qual os seguros de responsabilidade civil são estruturados. Nos seguros de responsabilidade civil tradicionais, o acionamento da apólice dependerá de uma

63 Texto clássico e precursor, BENJAMIN, Antonio Herman V. A insurreição da aldeia global versus o processo civil clássico. In: FRANCO, António de Sousa et al. Textos: ambiente e consumo. Lisboa: Centro de Estudos Jurídicos, v. 1, 1996.

64 LEITE, José Rubens Morato; AYALA, Patryck de Araújo. Dano ambiental: do individual ao coletivo extrapatrimonial. São Paulo: Revista dos Tribunais, 2012, p. 240. 
reclamação de um terceiro, individualmente afetado, ou de vários, mas cada um promovendo, individualmente, suas próprias reclamações.

Transposta a questão para a reflexão sobre o terceiro difuso - e estando-se a tratar de danos ecológicos e danos difusos - o leque de possibilidades de reclamação será muito mais alargado. Este esclarecimento terá especial implicação quando for tratado o tema do sinistro ambiental e das formas de acionamento da cobertura do seguro. De momento, cumpre frisar:

\begin{tabular}{|llll|}
\hline \multicolumn{1}{|c}{ DIMENSÃO } & \multicolumn{1}{c}{ O TERCEIRO } & RECLAMAÇão & \multicolumn{1}{c|}{ DESTINAÇÃo } \\
Dano individual & Vítima/individual & Pela vítima & Própria vítima \\
Dano ecológico & Coletividade & Legitimados & Restauração Ecológica \\
& /Recursos Naturais & & \\
Difusos & Coletividade & Legitimados & Fundos \\
\hline
\end{tabular}

\section{RESPONSABILIDADE INTEGRAL: FORMAS DE REPA- RAÇÃO DE DANOS E A ATUAÇÃO DOS SEGUROS POR MEIO DAS COBERTUAS E INDENIZAÇÕES}

A responsabilidade integral é um tema complexo, que, no âmbito dos seguros pode ganhar contornos de particular conflitualidade. O princípio da reparação integral do dano está consagrado no artigo 944 do Código Civil brasileiro, impondo que todos os prejuízos sofridos devem ser reparados. Quando transposto ao Direito Ambiental, determina que

[...] a reparação do dano ambiental conduza o meio ambiente e a coletividade a situação mais próxima possível daquela que existiria caso a lesão não tivesse ocorrido, [de modo que a] reparação dos danos ao meio ambiente deve ocorrer de maneira bastante ampla, envolvendo tanto os danos ecológicos puros quanto os danos causados por intermédio do meio ambiente, sejam eles individuais ou coletivos, patrimoniais ou extrapatrimoniais ${ }^{65}$.

65

BAHIA, Carolina Medeiros. Nexo de causalidade em face do risco e do dano ao meio ambiente: elementos para um novo tratamento da causalidade no sistema brasileiro de responsabilidade civil ambiental. Tese (Doutorado em Direito) - Centro de Ciências Jurídicas, Universidade Federal de Santa Catarina. Florianópolis, 2012, p. 140. 
Cumpre apreciar a incidência desse princípio nas diversas dimensões de danos e nas respectivas coberturas pelos seguros.

\subsection{Danos ecológicos, valoração, marco de reparação e despesas de contenção: tomada de posição}

A questão da valoração do dano ambiental, para além de polêmica, é altamente complexa ${ }^{66}$. Bergkamp, por exemplo, afirma que a impossibilidade de valoração dos bens naturais - e os custos associados à reparação - são um empecilho à assegurabilidade ${ }^{67}$. Considerando a problemática da valoração e o fato de que o maior valor e utilidade que os ecossistemas possam atingir e propiciar está justamente em seu pleno e íntegro funcionamento, sobressai a constatação de que a restauração natural é a modalidade preponderantemente prioritária em face dos danos ecológicos.

Assim, a prestação do segurador, definida na cobertura do seguro e concretizada na "indenização securitária" em caso de sinistros, deve ser prestada em serviços de restauração ambiental. Ou seja, em vez do mero reembolso ao segurado pelas despesas que ele suportou, até o valor limite da cobertura (LMI - Limite Máximo de Indenização), a prestação pelos seguros deve ser direta, com respectiva remuneração àquelas (empresas ou pessoas) que realizaram os serviços de restauração ambiental. Na Espanha, por exemplo, já assim atua o PERM: as apólices oferecem justamente os serviços de restauração, nos casos de coberturas para danos ecológicos.

A vantagem de tal modalidade está em manter os custos de reparação no controle do segurador, viabilizando sua adequada valoração e, ademais, propiciando uma base de informações sobre sinistros já ocorridos e indenizados, permitindo criar um banco de experiências que serão úteis para

66 MELO, Melissa Ely. Pagamento por serviços ambientais (PSA): entre a proteção e a mercantilização dos serviços ecossistêmicos no contexto da crise ambiental. Tese. (Doutorado em Direito) - Centro de Ciências Jurídicas, Universidade Federal de Santa Catarina. Florianópolis, 2016, p. 207 e seguintes. Especificamente sobre a utilidade da adequada valoração, no caso dos serviços ecológicos ou ecossistêmicos, para esforços de tomada de decisão - como é o caso de definição e delimitação de coberturas. Afirma: "A valoração destes serviços, neste mesmo sentido, mesmo que não seja a solução para a questão de sua preservação, pode auxiliar na condução de um processo de tomada de decisões que gere efeitos positivos nesta gestão". Idem, p. 210.

67 BERGKAMP, Lucas. Environmental risk spreading and insurance. Review of European Community and International Environmental Law (RECIEL). Oxford: Blackwell, v. 12, n. 3, 2003, p. 277. Do original: "There is no market value for many natural resources, and valuation and quantification of natural resource damage remain controversial, evolving issues". 
o futuro. Assim, é em face da necessidade de definir o valor dos recursos naturais suscetíveis a danos que "se valorará a proximidade e abundância desses recursos, assim como o custo e possibilidade técnica de reparação e o valor dos serviços ambientais que prestam à sociedade" ${ }^{\prime 68}$.

Naturalmente, em qualquer dos cenários, a restauração estará condicionada - em seus termos, formas e tecnologias - à chancela do Poder Público. No Brasil, como regra, será mediante a aprovação de um Plano de Recuperação de Área Degradada (PRAD) pelo órgão ambiental competente.

Bessa trata das vantagens e da necessidade de estabelecimento de mecanismo de valoração:

[...] considerando-se que a restauração natural nem sempre é possível, a valoração pecuniária do ambiente natural lesado tem o relevante papel de contribuir para (i) viabilizar financeiramente alguma forma de compensação, quando impossível qualquer reparação - poluição sonora, por exemplo e (ii) tornar certa a indenização, quando cabível ${ }^{69}$.

Não obstante a existência de diversas tecnologias de valoração ambien$\operatorname{tal}^{70}$, carece a definição legal prévia de uma metodologia a ser empregada, a modo de tornar estável e previsível a valoração dos danos e dos custos de reparação. Isso será útil, afinal, para valorar e estipular as formas de compensação, quando a restauração não for possível, ou de indenização, quando aquela não for viável.

Cabe referir, ainda, a cobertura de custos de contenção de danos ambientais ou a utilização dos recursos (limites) de uma cobertura de danos ecológicos, para fins de contenção de danos. Neste ponto, ganha destaque o papel preventivo dos seguros ambientais, pois o intuito dessa cobertura é justamente de minorar os danos ou, no limite, sendo possível, de evitá-los. Tal cobertura liga-se, portanto, aos esquemas de resposta de

68 HERAS HERRÁIZ, José Luis. El pool español de riesgos mediambientales. Actuarios. Madrid: Instituto de Actuarios Españoles, n. 33, octubre 2013, p. 20-21. Tradução livre, do original em espanhol.

69 ANTUNES, Paulo de Bessa. A recuperação de danos ecológicos no direito brasileiro. Veredas do Direito, Belo Horizonte, v. 14, n. 29, p. 293-321, mai./ago. 2017, p. 301. Disponível em: <http://www.domhelder.edu.br/revista/index.php/veredas/article/view/1056>. Acesso em: 10 outubro. 2017.

70 Sobre os métodos de valoração ambiental, ver MELO, Melissa Ely. Pagamento por serviços ambientais (PSA): entre a proteção e a mercantilização dos serviços ecossistêmicos no contexto da crise ambiental. Tese. (Doutorado em Direito) - Centro de Ciências Jurídicas, Universidade Federal de Santa Catarina. Florianópolis, 2016, p. 246. 
emergência e contenção de danos. Sustenta-se, contudo, que os custos de contenção de sinistros devam ser albergados em uma cobertura específica, não se confundindo ou integrando quaisquer das outras coberturas, nem, especificamente, a cobertura para danos ecológicos.

Uma derradeira questão diz respeito ao marco de reparação (baseline). O que se apresenta como dificuldade, notadamente para fins de seguros, é a definição do que seja a situação mais próxima possível daquela que existiria caso a lesão não tivesse ocorrido. É preciso delimitar o marco de reparabilidade a que se deverá retroagir para recompor o meio ambiente lesado. Essa determinação exige uma prévia delimitação do marco de reparação. Afinal, assim como não é lídimo dar às vítimas mais do que aquilo que perderam, tampouco é correto impor ao agente poluidor/degradador, ou transferir ao segurador, um encargo superior àquele que esteja atrelado ao evento danoso. A propósito, afirma Matos que é fundamental

[...] a descrição do "estado inicial", ou seja, da situação existente no momento da ocorrência do dano causado aos recursos naturais, porquanto essa mesma descrição assume uma particular importância para a fixação das medidas indemnizatórias de restituição natural. Igualmente significativas se traduzem as indicações fornecidas acerca dos programas e medidas para prevenção e reparação dos danos ambientais a adoptar no respectivo sector de actividade, procedendo nessa sede à determinação dos custos coenvolvidos em tais medidas ${ }^{71}$.

Essa base de informação prévia sobre o estado inicial pode ser útil para fins de delimitação do âmbito de responsabilidade do segurador; para fins de atendimento da legislação ambiental, contudo, pode ser insuficiente. A palavra última sobre o nível de reparação é uma decisão do órgão ambiental. Como explica Antunes,

[...] a recuperação ecológica é submetida a uma avaliação do órgão de controle ambiental que determina os seus limites. Cuida-se de uma medida de proporcionalidade entre o nível de recomposição da biota afetada e a sensível questão dos custos das atividades reparatórias do ambiente. Ademais, é necessário que

71 MATOS, Filipe Albuquerque. Danos ambientais / danos ecológicos: o fundo de intervenção ambiental. In: MONTEIRO, Jorge Sinde; BARBOSA, Mafalda Miranda (Coord.). Risco ambiental: atas do colóquio de homenagem ao Senhor Professor Doutor Adriano Vaz Serra. Coimbra: Instituto Jurídico/FDUC, 2015, p. 70. 
se estabeleça qual é o limite ótimo de recuperação, pois efetivamente as medidas de recuperação natural devem, necessariamente, deixar espaço para que a natureza, após um estímulo planejado e adequado ao caso concreto - as medidas promovidas no processo de recuperação -, siga o seu curso independentemente da ação humana. Os bens naturais não podem ser substituídos por outros iguais, pois um pássaro morto não retornará à vida; logo, o que se busca é um equivalente, o mais aproximado possível do que foi perdido ${ }^{72}$.

O ponto de recuperação ou de restauração, portanto, é definido com base em uma análise técnica, cuja incumbência Antunes pontua:

A recuperação é uma solução técnica definida pelo órgão de controle ambiental, conhecida como Plano de Recuperação de Áreas Degradadas (PRAD). Os diferentes órgãos de controle ambiental são dotados de regras próprias para a definição do procedimento a ser adotado pelo causador do dano - ou seus sucessores - para a recuperação das áreas lesadas ${ }^{73}$.

Conclui que:

[...] a reparação dos danos ecológicos se faz prioritariamente por meio da restauração natural que, como foi visto, não se confunde com uma abstrata volta a um passado prístino e sem intervenção humana. Ao contrário, a reparação ecológica é definida por um programa de recuperação que indica os limites do que se deve recuperar e como a recuperação deve ser realizada ${ }^{74}$.

Em que pese a solução útil e prática viabilizada pelo PRAD, persiste o problema da definição do ponto inicial de restauração ou recuperação, inclusive para servir de baliza ao PRAD. O instrumento próprio para diagnosticar um determinado estado ambiental ou ecológico é o Estudo Prévio de Impacto Ambiental, devidamente chancelado pela licença ambiental. Para fins de seguros e de delimitação do âmbito do dever de indenizar do segurador, para promover a recuperação ou restauração

72 ANTUNES, Paulo de Bessa. A recuperação de danos ecológicos no direito brasileiro. Revista Veredas do Direito. Belo Horizonte, v. 14, n. 29, maio/agosto 2017, p. 307.

73 ANTUNES, Paulo de Bessa. A recuperação de danos ecológicos no direito brasileiro. Revista Veredas do Direito. Belo Horizonte, v. 14, n. 29, maio/agosto 2017, p. 309-310.

74 ANTUNES, Paulo de Bessa. A recuperação de danos ecológicos no direito brasileiro. Revista Veredas do Direito. Belo Horizonte, v. 14, n. 29, maio/agosto 2017, p. 318. 
do bem ambiental, o EIA servirá de referência, contudo o segurador não estará limitado a isso. Poderá, com técnica e instrumentos próprios, definir outro marco inicial ou ponto ótimo de restauração, a ser acordado conjuntamente com o segurado. Uma mais ou menos completa delimitação do ponto de restauração influenciará o âmbito da garantia do seguro, afetando o valor do prêmio e viabilizando a sua contratação.

\subsection{Os seguros diante os danos ambientais difusos e extrapatrimoniais}

Não é correta a afirmação de que os danos extrapatrimoniais não devam ser amparados pelos seguros, segundo o argumento de que possuem destacado papel punitivo (punitive damages) e de que os seguros não devam cobrir penalidades. Em primeiro lugar, porque, sim, há coberturas de seguros para penalidades ${ }^{75}$ e, além disso, inexiste norma proibitiva. Segundo, e mais importante, é que toda condenação ou toda imposição do dever de indenizar carrega um objetivo dissuasório e punitivo.

É bem verdade que, na forma da lei, a indenização deva ser medida pela extensão dos danos, e não teria, em princípio, escopo punitivo (pedagógico). Contudo, é bem sabido - é uníssona a doutrina, e a jurisprudência convalida - que em toda condenação e indenização por danos extrapatrimoniais há, ao menos em sede argumentativa, forte preocupação com o caráter punitivo ${ }^{76}$. Fato é que há, nas indenizações por danos extra-

75 Tome-se por exemplo a Circular SUSEP553/2017, que expressamente autoriza coberturas para multas e penalidades civis, na forma do seu artigo $5^{\circ}, \$ 5^{\circ}$, verbis: "Art. $5^{\circ}$ No seguro de RC D \& O, a sociedade seguradora garante aos segurados, quando responsabilizados por danos causados a terceiros, em consequência de atos ilícitos culposos praticados no exercício das funções para as quais tenham sido nomeados, eleitos e/ou contratados, o reembolso das indenizações que forem obrigados a pagar, a título de reparação, por sentença judicial transitada em julgado, ou em decorrência de juízo arbitral, ou por acordo com os terceiros prejudicados, com a anuência da sociedade seguradora. [...] $\$ 5^{\circ}$ A garantia poderá abranger cobertura de multas e penalidades cíveis e administrativas impostas aos segurados quando no exercício de suas funções, no tomador, e/ou em suas subsidiárias, e/ou em suas coligadas.

76 Sobre o tema, ver SOARES, Flaviana Rampazzo. Revisitando o tema punitive damages, o ideal indenizatório e a função punitiva no direito de danos contemporâneo. In: $V$ Encontro Internacional do CONPEDI Montevidéu - Uruguai. Direito civil contemporâneo II. GONÇALVES, Everton das Neves Gonçalves; STELZER, Joana; POZZETTI, Valmir César. Florianópolis: CONPEDI, 2016, p. 78-98. Sustenta a autora que "esse fenômeno, em certa medida, representa uma distorção das funções do direito de danos, dificultando seu entendimento e sua aplicação, em razão da existência de discurso jurisprudencial que menciona uma função punitiva no direito de danos, porém, distante da prática, pois as indenizações geralmente fixadas na jurisprudência brasileira não refletem uma real e efetiva função punitiva”. Da mesma autora, vide SOARES, Flaviana Rampazzo. Culpa e castigo. Revista de Estudos Jurídicos e Sociais-REJUS ON LINE, v. 1, n. 01, nov. 2017. ISSN 2594-7702. Disponível em: <http://www.univel.br/ojs/ index.php/revista/article/view/19>. Acesso em: 30 abr. 2018. 
patrimoniais difusos, o escopo reparatório. No caso, não das perdas e danos das vítimas individualmente consideradas, mas de toda a coletividade, pela perda ou diminuição do proveito na fruição dos serviços ecológicos ou da própria qualidade ambiental.

Quanto à destinação dos recursos a um fundo, igualmente não se justifica a resistência de parte dos seguros. O direcionamento aos fundos é solução que se apresenta para que ocorra, oportunamente, o adequado encaminhamento dos recursos a medidas de reparação do dano difuso. Como explica Antunes,

O FDD tem sua origem na Lei da Ação Civil Pública (Lei Federal $\left.n^{\circ} 7.347 / 1985\right)$, que determina que "havendo condenação em dinheiro, a indenização pelo dano causado reverterá a um fundo", cuja destinação será para a "reconstituição dos bens lesados". Percebe-se que há uma contradição na norma, pois a indenização não se confunde com a hipótese de reconstituição dos bens lesados, visto que esta última é uma obrigação de fazer que se consubstancia em um PRAD. Atualmente o FDD é regido pelo Decreto $n^{\circ} 1.306$, de 9 de novembro de 1994. É importante registrar que os recursos arrecadados pelo FDD deverão ser utilizados em atividades "relacionadas com a natureza da infração ou de dano causado", buscando-se a "reparação específica do dano causado, sempre que tal fato for possível", ou seja, reconheceu-se a impossibilidade da repristinação ao chamado status quo ante ${ }^{77}$.

É fundamental que se organize um sistema concatenado para garantias pela via dos seguros. A cobertura para danos extrapatrimoniais não poderá servir como mero repasse do segurador ao fundo público, perdendo o segurador o controle da destinação. Tampouco se pode correr o risco de o recurso não ser diretamente destinado a compensar aqueles danos decorrentes da atividade assegurada. Há necessidade de um sistema que articule o setor público e privado, para que o Poder Público não veja o segurador como fonte de arrecadação e suprimento de seus fundos, o que permitiria, por exemplo, a gravosa situação de reclamar os valores das coberturas nos seus limites, sem adequada equivalência aos danos (a gravidade, a amplitude) que devem ser reparados.

77 ANTUNES, Paulo de Bessa. A recuperação de danos ecológicos no direito brasileiro. Veredas do Direito, Belo Horizonte, v. 14, n. 29, p. 293-321, mai./ago. 2017, p. 315. Disponível em: <http://www.domhelder.edu.br/revista/index.php/veredas/article/view/1056>. Acesso em: 10 outubro.2017. 


\subsection{Os danos individuais e sua projeção massificada: tomada de posição pelos seguros obrigatórios em um modelo de first-party insurance}

Os danos individuais, ao contrário dos ecológicos e dos difusos, são exemplos típicos de riscos tradicionalmente amparados pelos seguros, sobre os quais existe vasta experiência no setor segurador. O que ocorre é que, transpondo-se o universo dos danos individuais para o dos riscos ambientais, haverá, geralmente, se não sempre, situação com potencial multiplicação de indivíduos lesados. Considere-se, por exemplo, a situação de exposição de grupos vulneráveis em regiões próximas a empreendimentos industriais e sujeitos a riscos ambientais - circunstância em que haverá, em caso de sinistro, enorme massificação de danos. Furedi detém-se sobre o tema da vulnerabilidade:

O termo vulnerabilidade é habitualmente usado como se se tratasse de uma característica permanente de um dado perfil biográfico. A vulnerabilidade é apresentada e experienciada como um estado natural, que molda a reacção do ser humano. Trata-se de um rótulo para designar grandes grupos da sociedade. É essa a razão pela qual passou a ser comum utilizar o conceito - recentemente construído ${ }^{78}$ - de grupos vulneráveis. A expressão "grupo vulnerável" não designa só grupos de pessoas psicologicamente abaladas ou uma pequena minoria de indivíduos desprovidos de segurança económica ${ }^{79}$.

78 A propósito, “O sentimento de vulnerabilidade está de tal forma entranhado no nosso imaginário cultural, que facilmente nos passa despercebido o facto de se tratar de um conceito só recentemente inventado. A expressão 'grupo vulnerável' começou a ser usada na década de 1980. [...] Antes de meados dos anos 80, eram raras as ocorrências da expressão, que passa a ser amplamente utilizada entre 1985 e 1987 (LexisNexis 1960-2004). Mais importante do que isso parece ser o facto de, em finais da década de 80 , o significado da palavra 'vulnerável' ter sofrido uma transformação, passando a referir a identidade intrínseca da pessoa. A partir de então a expressão significa não só a relação do indivíduo com as suas circunstâncias, como por exemplo a pobreza, mas uma condição inerente ao próprio indivíduo. A nova expressão 'os vulneráveis' traduz perfeitamente essa evolução. A mudança do adjectivo 'vulneráveis a...' para o substantivo 'os vulneráveis' consolida a ideia da impotência como um estado, como uma forma de existir.' FUREDI, Frank. Para uma sociologia do medo. In: MENDES, José Manuel de Oliveira (Coord.). Risco, cidadania e Estado num mundo globalizado. Coimbra: Contexto, CES - Centro de Estudos Sociais, 2013, pp. 205-206.

79 FUREDI, Frank. Para uma sociologia do medo. In: MENDES, José Manuel de Oliveira (Coord.). Risco, cidadania e Estado num mundo globalizado. Coimbra: Contexto, CES - Centro de Estudos Sociais, 2013, p. 204. 
Os danos massificados (mass torts) se caracterizam pelo atingimento de uma multiplicidade de pessoas, contudo a quantidade não constitui o único critério, devendo ser levados em conta, ainda, a dispersão geográfica, a dispersão temporal ou latência do dano e a repetição de padrões fáticos ${ }^{80}$.

A reflexão gira em torno da assegurabilidade dos danos individuais massificados. Sobre essa dimensão, sustentamos que, para tais riscos, se faz necessária a instituição de seguros obrigatórios, que forneçam resposta imediata para o atendimento e a reconstrução pessoal e patrimonial das vítimas diretamente impactadas por um desastre. É nesse ponto, justamente, que os seguros evidenciam seu potencial como instrumento em favor da construção de resiliência.

Tratando-se de seguros obrigatórios, vislumbra-se a possibilidade de ação direta do terceiro contra o segurador, reclamando indenização conforme os danos que forem demonstrados na apuração do sinistro (regulação e liquidação), o que servirá como forma de resposta imediata para atendimento das vítimas. Tal modelo já existe, por exemplo, na Colômbia, onde há previsão na Lei 491/1999 sobre seguro obrigatório para cobrir os prejuízos económicos quantificáveis a pessoas determinadas como parte ou como consequência de danos ao meio ambiente e aos recursos naturais, sendo tal obrigatoriedade extensível a todas as atividades humanas que possam causar danos quantificáveis a pessoas determinadas e que estejam sujeitas ao licenciamento ambiental ${ }^{81}$.

Alternativamente, e reforçando a preocupação de atendimento emergencial em favor das vítimas, sugere-se a construção de um modelo obrigatório, não na modalidade de seguros de responsabilidade civil, mas de danos patrimoniais e pessoais (acidentes pessoais). Ou seja, um misto de seguro de dano (patrimonial) com seguro de pessoas (acidentes pessoais), nos quais os segurados serão cada uma das pessoas expostas em um determinado raio de risco. No caso, o poluidor-operador-empreendedor figurará não na condição de segurado - como nos seguros de responsabilidade civil - mas de "estipulante", responsável pelo pagamento dos prêmios. Seria possível, nesse cenário, o rateio do prêmio entre o estipulante, o Estado e, eventualmente, entre as próprias pessoas expostas (inclusive, se for do interesse, para fins de incremento do capital segurado). Seria, então, uma modalidade de seguro ambiental

80 MALO, Albert Azagra. Daños del amianto: litigación, aseguramiento de riesgos y fondos de compensación. Madrid: Fundación Mapfre, 2011, p. 23.

81 Sobre o tema, ver PRIETO, Hilda Esperanza Zornosa. Comentarios a la ley colombiana 491 de seguro ecológico expedida el 13 de enero de 1999. In: PRIETO, Hilda Esperanza Zornosa. Escritos sobre riesgos y seguros. Bogotá: Universidad Externado de Colombia, 2012, pp. 596 e seguintes. 
obrigatório para proteger as pessoas em situação de vulnerabilidade, que vivam em regiões de risco.

Essa proposta agrega ao enfrentamento da questão do risco moral e da seleção adversa na medida em que as possíveis vítimas figurariam na condição de seguradas; isso tornaria essa modalidade um seguro first-party, carreando vantagens para a precificação, pois possibilita a identificação do terceiro.

Um ponto de análise deve ser procedido a partir da reflexão sobre quem é ou quem está exposto ao risco - o segurado diretamente ou o segurado indiretamente. $\mathrm{O}$ risco diretamente do segurado, à sua pessoa e seus bens, vincula-se à figura dos seguros patrimoniais, quando os riscos sobre ele recaem diretamente (first-party insurance). Diferente é a possibilidade de riscos que indiretamente recaiam sobre o segurado, e isto é típico dos seguros de responsabilidade civil (third-party insurance), ou seja, o risco de o segurado ser responsabilizado decorre do risco de um terceiro sofrer um prejuízo (e reclamar a reparação do mesmo) $)^{82}$.

Isso tem relevante consequência na previsibilidade dos riscos que serão tomados pelo segurador, pois, no primeiro caso, a projeção de risco é mais viável, já que o segurador tem uma relação contratual direta com a potencial vítima, que será o próprio segurado. Assim, transforma-se em modelo da segunda categoria, pois o segurador não pode, antecipadamente, prever quem serão os terceiros (e aqui podemos remeter à questão da percepção dos riscos, bem como às dimensões de danos ambientais, ambos tratados no capítulo inicial). Mais do que isso, enquanto no first-party insurance o segurador, como conhece o sujeito e sua realidade, pode escolher seus segurados (inclusive rejeitando) e valorar possíveis impactos (projetando tanto no preço quanto no incremento das delimitações), nos seguros de responsabilidade (third-party insurance) esse conhecimento é dificultoso e, a depender da extensão, impossível ${ }^{83}$.

82 BERGKAMP, Lucas. Environmental risk spreading and insurance. Review of European Community and International Environmental Law (RECIEL). Oxford: Blackwell, v. 12, n. 3, 2003, p. 272. 83 BERGKAMP, Lucas. Environmental risk spreading and insurance. Review of European Community and International Environmental Law (RECIEL). Oxford: Blackwell, v. 12, n. 3, 2003, p. 273. O autor afirma que o first-party insurance é uma alternativa aos seguros de responsabilidade civil tradicional. Neste sentido - e neste ponto o autor se refere à poluição gradual em oposição à súbita, que são categorias já foram diferidas (conforme consta no capítulo 1) - para determinadas situações de risco (riscos graduais) um seguro direto do terceiro apresenta-se como solução possível para assegurabilidade. Afirma: "While this type of damage could not be covered in the liability context, it does not pose barriers to coverage by a frst-party policy. [...] developments in liability law make it attractive for insurers to consider alternatives for the classical liability insurance, specifically alternatives that allow the insurer, not the courts, to define the scope of coverage. In a third-party context, many types of environmental damage 
Para BERGKAMP, houve claro equívoco da Comissão responsável pela edição da Diretiva, que, segundo ele, teria agido melhor se tivesse optado por um modelo de first-party insurance em vez do modelo tradicional de seguros de responsabilidade civil. Assevera, ainda, ser vaga a noção do que seja, em determinados ordenamentos, o dano aos recursos naturais e à biodiversidade ${ }^{84}$. O presente estudo, pretende-se, servirá de base, ainda que inicial, para se avançar nestas modelagens no cenário brasileiro.

\section{O SEGURO GARANTIA AMBIENTAL}

O seguro garantia, em sua modalidade ou escopo ambiental, pressupõe a existência de um dano ambiental. Enquanto no seguro de responsabilidade civil ambiental o risco está na possibilidade de dano, no seguro garantia, o dano, e um passivo, é pressuposto, quando o risco estará atrelado à obrigação de repará-lo e à possibilidade de o responsável por ele, assumindo ou sendo-lhe imposta a obrigação de reparar, deixar de fazêla. Sua utilidade é específica, portanto, em face dos danos ecológicos.

Havendo um passivo e a determinação do Poder Público por sua recuperação, poderá o órgão ambiental exigir uma garantia de prestação e de execução da obrigação. Nesse caso, o Poder Público (seja o órgão ambiental ou o Ministério Público, por exemplo) atuará como segurado, enquanto o responsável pela área ou recurso natural contaminado ou degradado figurará como tomador do seguro. É em face do não cumprimento de sua obrigação que incidirá e atuará o seguro garantia ambiental. Conforma um seguro garantia na modalidade performance bond, ou seguro garantia de execução, que atuará "até o valor fixado na apólice, dos prejuízos decorrentes de inadimplemento do tomador com relação a obrigações assumidas [...], firmado entre ele e o segurado, e coberto pela apólice" 85 .

Em dois cenários o seguro garantia ambiental poderá atuar de forma destacada: para garantir as obrigações assumidas em um TAC ou para satisfazer exigência, pelo órgão ambiental, de recuperação de áreas

\footnotetext{
are not insurable, or are insurable only to a limited degree". BERGKAMP, Lucas. Environmental risk spreading and insurance. Review of European Community and International Environmental Law (RECIEL). Oxford: Blackwell, v. 12, n. 3, 2003, p. 276.

84 BERGKAMP, Lucas. Environmental risk spreading and insurance. Review of European Community and International Environmental Law (RECIEL). Oxford: Blackwell, v. 12, n. 3, 2003, pp. 278-279.

85 BURANELLO, Renato Macedo. Do contrato de seguro - o seguro garantia de obrigações contratuais. São Paulo: Quartier Latin, 2006, p. 192.
} 
degradadas ou contaminadas, em caso, por exemplo, de desativação de atividades.

Em relação ao TAC: estando um proprietário de imóvel em situação de irregularidade, em razão, por exemplo, de não manutenção, uso inadequado ou supressão de vegetação em APP, e sendo constatada tal situação pelo Ministério Público em ICP ou pelo próprio órgão ambiental em vistoria ou ação de fiscalização, firma-se um TAC que exija, para a recuperação da área, uma garantia de cumprimento segundo o PRAD. Para garantir a performance com a qual se comprometeu, e com uma adequada execução do $\mathrm{PRAD}$, poderá ser oferecido ou exigido pelo poder público um seguro garantia ambiental. O risco de tal modalidade de seguro é o inadimplemento. Outro exemplo é a desativação de atividades: será imposta a obrigação de reparar o passivo, e o empreendedor assumirá obrigações mediante um plano de desativação e remediação de áreas contaminadas ${ }^{86}$ seguindo a mesma lógica de garantia de uma obrigação assumida como essa que presentemente se propõe.

\section{CONSIDERAÇÕES FINAIS}

O tema dos seguros ambientais, no Brasil, embora tenha origem ainda na década de 1980, ainda é bastante incipiente. Por serem os seguros, inclusive os ambientais, essencialmente mecanismos de mercado, logo, também são instrumentos essencialmente econômicos, e o desenvolvimento do tema e de sua utilidade está diretamente relacionado ao desenvolvimento do próprio mercado de seguros ambientais, ou seja, demandas por essas modalidades de garantia e oferta de produtos adequados pelo mercado segurador.

Os seguros ambientais, especialmente nos últimos dez anos, vêm ganhando novas expressões e despertando maior importância com o incremento do interesse do mercado consumidor de tais tipos de seguros; com a compreensão da necessidade, pelo Poder Público, de vinculação e subsidiariedade dos seguros ambientais às atividades de controle e licenciamento; e, por consequência, pelo aumento de produtos de seguros ambientais disponibilizados pelo mercado segurador, seja com o

86 Sobre a desativação de empreendimentos minerários, ver POVEDA, Eliane Pereira Rodrigues. A eficácia legal na desativação de empreendimentos minerários. São Paulo: Signus, 2007; __. Seguro garantia como instrumento econômico para a implementação do gerenciamento de áreas contaminadas. Revista Síntese Direito Ambiental. Ano I - no 3 (out. 2011), p. 78-89, São Paulo, IOB, 2011; bem como . Seguro garantia como instrumento econômico para a sustentabilidade na mineração. Revista de Direito Ambiental. Ano 17. Vol. 65. (Jan.-Mar.2012). São Paulo: Revista dos Tribunais, 2012. 
ingresso de novos seguradores no cenário nacional, seja com a prática criativa de desenvolvimento de soluções e estratégias para novos riscos, o que é característico desde as origens do instituto dos seguros.

Tal estágio de desenvolvimento impõe ao Direito e aos juristas a adequada compreensão e conformação desse novo cenário de seguros, objetivando sua adequação jurídica, para que os seguros ambientais, como instrumentos econômicos, sejam aprimorados e adequados ao atendimento, por um lado, da viabilidade do negócio e da atividade de seguros e, por outro, para que tal instrumento sirva como ferramenta útil de garantia de reparação dos danos ambientais e, por consequência, de proteção do meio ambiente.

Esse estudo objetivou, portanto, contribuir com tal desenvolvimento na seara jurídica, apresentando elementos e conceitos próprios do instituto dos seguros para, entendida sua funcionalidade, viabilizar interfaces com os riscos ambientais e com seu asseguramento. Buscou-se cumprir tal desiderato a partir do estabelecimento e conceituação das diversas categorias de seguros ambientais possíveis, em um primeiro momento, para, em seguida, sugerir formas de atuação, de adequação e de ampliação da utilidade de cada uma das modalidades.

Promovida a necessária reflexão sobre os grandes temas que direita e indiretamente se relacionam com seguros ambientais, contribui-se para o devido debate e aprofundamento do tema em nível jurídico e político no Brasil, seja pelas questões problematizadoras suscitadas e aprofundadas nesse estudo, seja especialmente pelo seu papel contributivo, na medida em que se buscou inovar, apresentando quais são as principais adequações que deverão ser desenvolvidas e aprimoradas para a estruturação de uma política de garantias de reparabilidade de danos ambientais com base nos seguros.

\section{REFERÊNCIAS}

ALMADA, Beatriz de Moura Campos Mello. O seguro garantia como mitigador de riscos nos grandes projetos. In: SCHALCH, Debora (org.). Seguros e resseguros: aspectos técnicos, jurídicos e econômicos. São Paulo: Saraiva/Virgília, 2010.

ALVAREZ, Ana Maria Blanco Montiel. Resseguro e seguro: pontos de contato entre negócios jurídicos securitários. Porto Alegre: Livraria do Advogado, 2014.

ANDRADE, Fábio Siebeneichler de. O desenvolvimento do contrato de seguro no direito civil brasileiro atual. Revista de Derecho Privado. Bogotá: Universidad Externado de Colombia, n. 28, enero-junio, 2015. 
ANTUNES, Paulo de Bessa. A recuperação de danos ecológicos no direito brasileiro. Revista Veredas do Direito. Belo Horizonte, v. 14, n. 29, maio/agosto 2017.

BAHIA, Carolina Medeiros. Nexo de causalidade em face do risco e do dano ao meio ambiente: elementos para um novo tratamento da causalidade no sistema brasileiro de responsabilidade civil ambiental. Tese (Doutorado em Direito) - Centro de Ciências Jurídicas, Universidade Federal de Santa Catarina. Florianópolis, 2012.

BAPTISTA DA SILVA, Ovídio A. O seguro e as sociedades cooperativas: relações jurídicas comunitárias. Porto Alegre: Livraria do Advogado, 2008.

BARBAT, Andrea Signorino. Los seguros de responsabilidad civil: caracteres generales y coberturas principales. Montevideo: Fundación de Cultura Universitaria, 2011.

BECHARA SANTOS, Ricardo. Direito de seguro no Código Civil e legislação própria. Rio de Janeiro: Forense, 2006.

BENJAMIN, Antonio Herman V. A insurreição da aldeia global versus o processo civil clássico. In: FRANCO, António de Sousa et al. Textos: ambiente e consumo. Lisboa: Centro de Estudos Jurídicos, v. 1, 1996.

BERGKAMP, Lucas. Environmental risk spreading and insurance. Review of European Community and International Environmental Law (RECIEL). Oxford: Blackwell, v. 12, n. 3, 2003.

BRIYS, Eric; VARENNE, François de. Assurance et marches financiers: concurrence ou complémentarité? In: EWALD, François; LORENZI, Jean-Hervé. Encyclopédie de l'assurance. Paris: Economica, 1998.

BURANELLO, Renato Macedo. Do contrato de seguro - o seguro garantia de obrigações contratuais. São Paulo: Quartier Latin, 2006.

CAETANO, Matheus Almeida. Os delitos de acumulação no direito penal ambiental. São Paulo: Editora Pillares, 2016.

CARLINI, Angélica. A atividade de seguro no Brasil nos últimos cinquenta anos. Assicurazioni - Rivista di diritto, economia e finanza delle assicurazioni private. Roma: Fondazione Assicurazioni Generali, anno LXXV, n. 4, ottobre-dicembre, 2008.

COLOMBO, Angelo. Contrato de seguros: limites técnicos de negociação entre seguradora e segurado. In: SCHALCH, Debora (org.). Seguros e resseguros: aspectos técnicos, jurídicos e econômicos. São Paulo: Saraiva/Virgília, 2010.

CORDEIRO, António Menezes. Direito dos Seguros. Coimbra: Almedina, 2016.

FERREIRA SILVA, Rita Gonçalves. Do contrato de seguro de responsabilidade civil geral: seu enquadramento e aspectos jurídicos essenciais. Coimbra: Coimbra, 2007. 
FUREDI, Frank. Para uma sociologia do medo. In: MENDES, José Manuel de Oliveira (Coord.). Risco, cidadania e Estado num mundo globalizado. Coimbra: Contexto, CES - Centro de Estudos Sociais, 2013.

HERAS HERRÁIZ, José Luis. El pool español de riesgos mediambientales. Actuarios. Madrid: Instituto de Actuarios Españoles, n. 33, octubre 2013.

LEITE, José Rubens Morato. Manual de direito ambiental (coord.). São Paulo: Saraiva, 2015.

; AYALA, Patryck de Araújo. Dano ambiental: do individual ao coletivo extrapatrimonial. São Paulo: Revista dos Tribunais, 2012.

LUHMANN, Niklas. Sociología del riesgo. Coord. Tradución Javier Torres Nafarrate. México D.F.: Universidad Iberoamericana, 2006.

MALO, Albert Azagra. Daños del amianto: litigación, aseguramiento de riesgos y fondos de compensación. Madri: Fundación Mapfre, 2011.

MARTINEZ, Pedro Romano. Direito dos Seguros: apontamentos. S. João do Estoril: Principia, 2006.

MATOS, Filipe Albuquerque. Danos ambientais / danos ecológicos: o fundo de intervenção ambiental. In: MONTEIRO, Jorge Sinde; BARBOSA, Mafalda Miranda (Coord.). Risco ambiental: atas do colóquio de homenagem ao Senhor Professor Doutor Adriano Vaz Serra. Coimbra: Instituto Jurídico/FDUC, 2015.

MELO, Melissa Ely. Pagamento por serviços ambientais (PSA): entre a proteção e a mercantilização dos serviços ecossistêmicos no contexto da crise ambiental. Tese. (Doutorado em Direito) - Centro de Ciências Jurídicas, Universidade Federal de Santa Catarina. Florianópolis, 2016.

MONTI, Alberto. Environmental risks and insurance: a comparative analysis of the role of insurance in the management of environment-related risks. OCDE, 2002. Disponível em: <www.oecd.org/finance/financial-markets/1939368.pdf>. Acesso em: 18 nov. 2017.

PASQUALOTTO, Adalberto. Garantias no Direito das Obrigações: um ensaio de sistematização. Tese (Doutorado em Direito) - Faculdade de Direito, Universidade Federal do Rio Grande do Sul. Porto Alegre, 2005.

PERANDONES, Pablo Girgado. El principio indemnizatorio en los seguros de daños: una aproximación a su significado. MERCATURA - Coleción Estudios de Derecho Mercantil n. 19. Granada: Comares, 2005.

- La póliza estimada: la valoración convencional del interés en los seguros de daños. Madrid: Marcial Pons, 2015. 
PEREIRA, Fernanda. Fundamentos técnicos - atuariais do seguro. In: MIRAGEM, Bruno; CARLINI, Angélica. Direito dos seguros: fundamentos de direito civil, direito empresarial e direito do consumidor. São Paulo: Revista dos Tribunais, 2014.

POLIDO, Walter. Seguros para riscos ambientais. São Paulo: Revista dos Tribunais, 2005.

. Contrato de seguro: novos paradigmas. São Paulo: Roncarati, 2010.

. Resseguro: cláusulas contratuais e particulares sobre responsabilidade civil. $2^{\text {a }}$ ed. Rio de Janeiro: Funenseg, 2011.

POVEDA, Eliane Pereira Rodrigues. A eficácia legal na desativação de empreendimentos minerários. São Paulo: Signus, 2007.

. Seguro garantia como instrumento econômico para a implementação do gerenciamento de áreas contaminadas. Revista Síntese Direito Ambiental. Ano I - n ${ }^{\circ}$ 3 (out. 2011), São Paulo, IOB, 2011.

. Seguro garantia como instrumento econômico para a sustentabilidade na mineração. Revista de Direito Ambiental. Ano 17. Vol. 65. (Jan.-Mar.2012). São Paulo: Revista dos Tribunais, 2012.

PRIETO, Hilda Esperanza Zornosa. Escritos sobre riesgos y seguros. Bogotá: Universidad Externado de Colombia, 2012.

REGO, Margarida Lima. Contrato de seguro e terceiros: estudo de direito civil. Coimbra: Coimbra Editora/Wolters Kluwer, 2010.

SILVA, Ivan de Oliveira. Curso de direito do seguro. São Paulo: Saraiva, 2012.

SILVA SANTOS, Margarida. Seguro de crédito. Lisboa: Prime Books, 2004.

SOARES, Flaviana Rampazzo. Revisitando o tema punitive damages, o ideal indenizatório e a função punitiva no direito de danos contemporâneo. In: V Encontro Internacional do CONPEDI Montevidéu - Uruguai. Direito civil contemporâneo II. GONÇALVES, Everton das Neves Gonçalves; STELZER, Joana; POZZETTI, Valmir César. Florianópolis: CONPEDI, 2016.

. Culpa e castigo. Revista de Estudos Jurídicos e Sociais-REJUS ON LINE, v. 1, n. 01, nov. 2017. ISSN 2594-7702. Disponível em: $<$ http://www.univel.br/ojs/ index.php/revista/article/view/19>. Acesso em: 30 abr. 2018.

VASQUES, José. Contrato de seguro: notas para uma teoria geral. Coimbra: Coimbra Editora, 1999.

VEIGA COPO, Abel B. El riesgo en el contrato de seguro: ensayo dogmático sobre el riesgo. Cizur Menor (Navarra): Aranzadi, 2015. 